\title{
Deciphering the Jurassic-Cretaceous evolution of the Hamadan metamorphic complex during Neotethys subduction, western Iran
}

\author{
Behzad Monfaredi ${ }^{1} \odot$. Christoph Hauzenberger ${ }^{1} \cdot$ Franz Neubauer $^{2} \cdot$ Bernhard Schulz $^{3} \cdot$ Johann Genser $^{2}$. \\ Farzaneh Shakerardakani $^{4,5} \cdot$ Ralf Halama $^{6}$
}

Received: 10 April 2019 / Accepted: 8 June 2020 / Published online: 2 July 2020

(c) The Author(s) 2020

\begin{abstract}
The Hamadan high-grade metapelites in the northwestern part of the Sanandaj-Sirjan zone, Iran, show a polymetamorphic evolution with relics of a garnet-bearing metamorphic mineral assemblage (M1), a contact metamorphic overprint (M2) related to the emplacement of the Middle to Late Jurassic Alvand composite pluton and a Buchan-type regional metamorphic event (M3) marked by ${ }^{40} \mathrm{Ar} /{ }^{39} \mathrm{Ar}$ ages in the $80-70$ Ma range that is associated with penetrative ductile deformation producing a foliation and a thermal overprint onto the M2 assemblages. The M1 event is exclusively preserved as small garnet grains and mineral inclusions contained therein, incorporated into M2-stage cordierite porphyroblasts. Distinct metamorphic zones are developed over a region of $\sim 600 \mathrm{~km}^{2}$, which are partly correlated with distance to the composite pluton: zones (1) cordierite $+\mathrm{K}$-feldspar hornfels, and (2) andalusite \pm cordierite hornfels that surround the Alvand composite pluton at a distance of up to $5 \mathrm{~km}$. These two zones are clearly related to M2 metamorphism associated with pluton emplacement. Zones (3) staurolite schist, (4) andalusite schist, and (5) sillimanite schist are found outside of the contact aureole and are considered to be the result of regional M3 metamorphism in the eastern part distant to the Alvand composite pluton. Conventional thermobarometry shows that temperatures in the area vary between $\sim 560$ and $660{ }^{\circ} \mathrm{C}$ for zones 1 and 2 and $\sim 490$ and $690{ }^{\circ} \mathrm{C}$ for zones 3-5. Phase equilibria modelling in the MnNCKFMASHT system indicates two distinct isobaric prograde paths at low pressures, at $2.7 \mathrm{kbar}$ for zones 1 and 2 and slightly higher pressures of around 3.5-5.5 kbar for zones 3-5. U-Th-Pb monazite geochronology revealed overlapping ages of $168 \pm 11 \mathrm{Ma}$ and $149 \pm 19 \mathrm{Ma}$ in the hornfels (1 and 2) and schistose (3-5) zones, respectively. These ages are similar to the intrusion age of the Alvand composite pluton $(153.3 \pm 2.7$ to $166.5 \pm 1.8 \mathrm{Ma})$ and are interpreted to reflect heating due to the emplacement of the composite pluton (M2 contact metamorphic event). However, ${ }^{40} \mathrm{Ar} /{ }^{39} \mathrm{Ar}$ dating of white mica and amphibole yielded plateau ages ranging from 80 to $69 \mathrm{Ma}$ over the entire transect. The formation of schistosity in zones 3-5 postdates the intrusion and is thus related to M3 metamorphism. The white mica fabric indicates formation of the foliation during M3 garnet growth, which is followed by local retrogression of garnet to chlorite during exhumation. Consequently, the ${ }^{40} \mathrm{Ar} /{ }^{39} \mathrm{Ar}$ white mica and amphibole ages likely indicate reheating during M3 to more than ca. $500 \pm 25^{\circ} \mathrm{C}$ (argon retention temperature in amphibole). These data establish the occurrence of a Cretaceous, Buchan-style regional metamorphic event that had not been firmly identified before. Subsequent Late Cretaceous exhumation of the Hamadan complex with its high-grade metapelites is due to extension along the Tafrijan-Mangavi-Kandelan fault, which represents a major ductile low-angle normal fault. Metamorphic temperatures coupled with mineral ages from this and published work suggest a fast stage of cooling with a rate of $\sim 6{ }^{\circ} \mathrm{C} / \mathrm{Ma}$ during exhumation after M3 metamorphism.
\end{abstract}

Keywords Hamadan metamorphic complex · Sanandaj-Sirjan zone · Thermobarometry $\cdot(\mathrm{U}-\mathrm{Th})-\mathrm{Pb}$ monazite dating ·

${ }^{40} \mathrm{Ar} /{ }^{39} \mathrm{Ar}$ dating $\cdot$ Petrochronology

Electronic supplementary material The online version of this article (https://doi.org/10.1007/s00531-020-01893-x) contains supplementary material, which is available to authorized users.

Extended author information available on the last page of the article

\section{Introduction}

Metamorphic belts generally occur in central sectors of collisional orogenic belts and provide evidence for a number of superimposed tectonic processes like burial by subduction, 
subsequent heating and finally exhumation during collisional orogeny, with interposed subduction- and/or collisionrelated plutons that may cause additional contact metamorphic overprints. Therefore, the recognition of distinct metamorphic stages in such metamorphic terrains is crucial for the interpretation of their geotectonic history. To achieve this aim, combining information about time (ages and/or duration) to specific rock-forming processes and their physical conditions (e.g. temperature and pressure) is fundamental (Mottram et al. 2014; Engi et al. 2017).

The Zagros orogen (Iran) is a segment of the Alpine-Himalayan collision zone that resulted from closure of the Neotethys ocean and comprises an internal belt of collisionrelated metamorphic rocks (Stöcklin 1968; Berberian and King 1981; Mohajjel and Fergusson 2014; Shakerardakani et al. 2015; Hassandzadeh and Wernicke 2016). Within the Zagros orogen, the Sanandaj-Sirjan zone represents the metamorphic core of the Arabia-Eurasia collision and contains a record of its magmatic and metamorphic evolution (Hassandzadeh and Wernicke 2016). Among those debated, one issue is whether and to which way the metamorphic rocks are related to the collision process, and how the plate tectonic imprint affected the formation of different metamorphic grades in this belt, especially where low-pressure metamorphism within a contact aureole and Buchan-type metamorphism interfere with each other.

The Sanandaj-Sirjan zone plays a crucial role in deciphering the evolution of the Arabia-Eurasia collision, but its metamorphic history is still the least investigated aspect (Hassandzadeh and Wernicke 2016). The Hamadan metamorphic complex in the northwestern part of the Zagros collision zone is among the volumetrically most significant exposures of metamorphic rocks, but ages of protoliths and metamorphic events are in dispute. The Hamadan metamorphic complex exposes Middle to Late Jurassic granite and gabbro intrusions known as the Alvand composite pluton, dated at $172-153 \mathrm{Ma}$ based on $\mathrm{U}-\mathrm{Pb}$ zircon and monazite ages (Shahbazi et al. 2010; Mahmoudi et al. 2011; Sepahi et al. 2018) and is characterized by associated contact metamorphism. However, in some distance to the Alvand composite pluton, rocks of the Hamadan metamorphic complex are schistose and even a Late Jurassic granite gneiss, the Aliabad-e Damaq pluton, is schistose. Previous K-Ar mineral geochronology yielded, beside a single Early Cretaceous amphibole age, Late Cretaceous to Paleocene white mica and biotite ages for the metamorphic rocks as well as for the Alvand composite pluton itself (Valizadeh and Cantagrel 1975; Baharifar et al. 2004). The available observations and data do not allow a clear distinction whether the metamorphism in the Hamadan area is solely related to the emplacement of the plutonic rocks or whether several distinct metamorphic episodes occurred with distinct ages and pressure-temperature evolutions. These different interpretations imply either a long-lasting cooling history after intrusion of magmatic rocks or a more complex, polyphase metamorphic history.

Given the rather speculative metamorphic age assignments, the Hamadan metamorphic complex warrants a more detailed petrochronological study with the combined application of several petrological and geochronological methods to unravel superimposed metamorphic events. Consequently, the present study is aimed to clarify the petrology, $P-T$ conditions and the age(s) of metamorphism in the Hamadan metamorphic complex. Our approach describes the field relationships, petrography and mineral chemical characteristics of high-grade metapelitic rocks from the Hamadan complex, as well as $P-T$ results obtained by conventional thermobarometry and equilibrium assemblage diagrams using the THERIAK/DOMINO software (de Capitani and Brown 1987; de Capitani and Petrakakis 2010). We also present results of chemical U-Th- $\mathrm{Pb}$ monazite ages and a comprehensive data set of laser-probe ${ }^{40} \mathrm{Ar} /{ }^{39} \mathrm{Ar}$ muscovite and amphibole ages from different metamorphic zones allowing a better understanding of the petrochronological evolution of the Hamadan complex for which previously only $\mathrm{K}-\mathrm{Ar}$ ages and fission track data existed (Baharifar et al. 2004; François et al. 2014).

In this study, we closely consider the relationships among distinct metamorphic events and the emplacement of Jurassic subduction-related plutons and develop a model with three stages of metamorphism ranging from pre-pluton emplacement (M1) via Middle/Late Jurassic contact metamorphism (M2) associated with emplacement of the composite Alvand pluton to a nearly pervasive Late Cretaceous thermal overprint (M3) partly associated with ductile deformation. The metamorphic stage M3 was not considered before for this region. We offer, therefore, a new model for the tectono-metamorphic evolution of the Hamadan complex where metamorphic stages M2 and M3 relate to distinct, separate stages during closure of the Neotethys.

\section{Geological setting}

Formation of the Zagros orogen results from the long-lasting convergence between Eurasia and Gondwana-derived fragments during closure of the Neotethys Ocean (e.g., Agard et al. 2005, 2011). The Sanandaj-Sirjan zone is in most parts a polymetamorphic zone within the interior part of the Zagros orogen that contains abundant Mesozoic calcalkaline plutons, which caused contact metamorphism of surrounding rocks (e.g., Stöcklin 1968; Berberian and King 1981; Mohajjel et al. 2003; Agard et al. 2005, 2011; Chiu et al. 2013; François et al. 2014; Shakerardakani et al. 2015; Hassanzadeh and Wernicke 2016; Sepahi et al. 2018). The distribution of metamorphic rocks is discontinuous and 
different metamorphic evolutions have been observed in different areas of the Sanandaj-Sirjan zone (Berberian and King 1981; Hassanzadeh and Wernicke 2016).

Previous work (e.g., Shakerardakani et al. 2015; Hassanzadeh and Wernicke 2016) interpreted the metamorphic rocks within the Sanandaj-Sirjan zone to exhibit up to four stages of metamorphic evolution (Berberian and King 1981) and, therefore, representing a polymetamorphic terrain. In the central part of the Sanandaj-Sirjan zone in the area of Shahrekord W of Esfahan, an early high-pressure metamorphic stage (max. $25 \mathrm{kbar}$ at $T=600{ }^{\circ} \mathrm{C}$; with ${ }^{40} \mathrm{Ar} /{ }^{39} \mathrm{Ar}$ phengite ages of ca. $184 \mathrm{Ma}$ ) likely relates to the accretion of a continental basement segment to Central Iran within the Neotethyan subduction system (Davoudian et al. 2016). Another metamorphic stage is related to contact metamorphism caused by Middle/Late Cretaceous plutons (Baharifar et al. 2004; Sepahi et al. 2004, 2019; Mohajjel et al. 2006).

The Hamadan high-grade metamorphic rocks ("lower unit" in the following text) with an extension of $\sim 600 \mathrm{~km}^{2}$ occur mainly southeast- and southward to the Alvand composite pluton, which is one of the largest Jurassic composite plutons in the Sanandaj-Sirjan zone (Fig. 1). The Hamadan

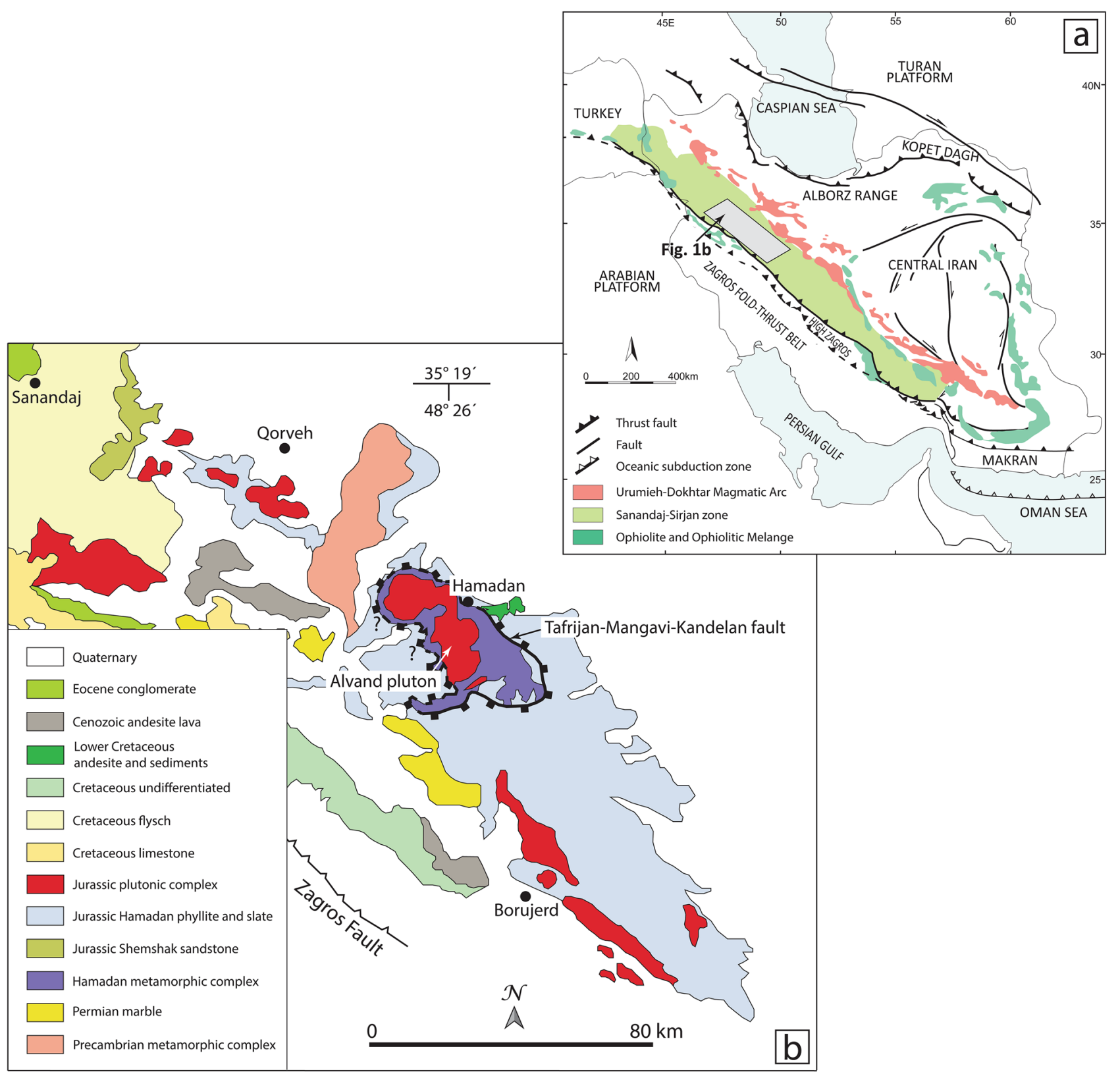

Fig. 1 Simplified geological map of northern Sanandaj-Sirjan zone modified after Mahmoudi et al. (2011). The Alvand composite pluton and Hamadan metamorphic complex are located in the centre of the map 
complex contains potentially Triassic and rare fossil-bearing Jurassic slates (e.g., bivalve Posidonia alpina Dehghan 1947), phyllites and micaschists. The slates are separated by a major normal fault (Tafrijan-Mangavi-Kandelan fault) from the amphibolite facies metamorphic rocks next to the Alvand composite pluton (Fig. 2) as already recognized by
Agard et al. (2005). This unit contains various metapelitic schists, rare amphibolite lenses and some pegmatites. To the east of Hamadan, the folded very low- to low-grade metamorphic rocks (but not the high-grade metamorphic rocks) are non-conformably overlain by a Lower Cretaceous succession with a thin basal conglomerate overlain

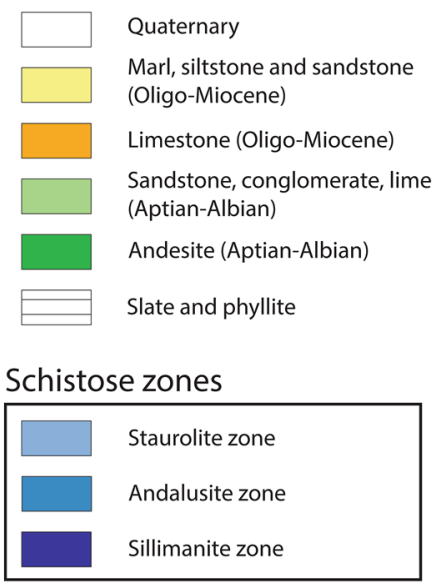

Hornfels zones

\begin{tabular}{|c|c|}
\hline & $\begin{array}{l}\text { Andalusite } \pm \text { cordierite zone } \\
\text { Cordierite } \pm \text { K-feldspar zone }\end{array}$ \\
\hline & Alvand pluton (granitoids) \\
\hline & Schistose granite (Aliabad granitic gneiss) \\
\hline D & Pegmatite dike \\
\hline 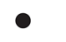 & Sample location of schistose rocks \\
\hline$\Delta$ & Sample location of hornfels rocks \\
\hline 0 & Sample location of amphibolites \\
\hline & Fault, inferred fault \\
\hline 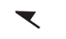 & Trust fault \\
\hline & Normal fault \\
\hline
\end{tabular}

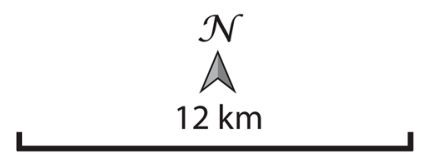

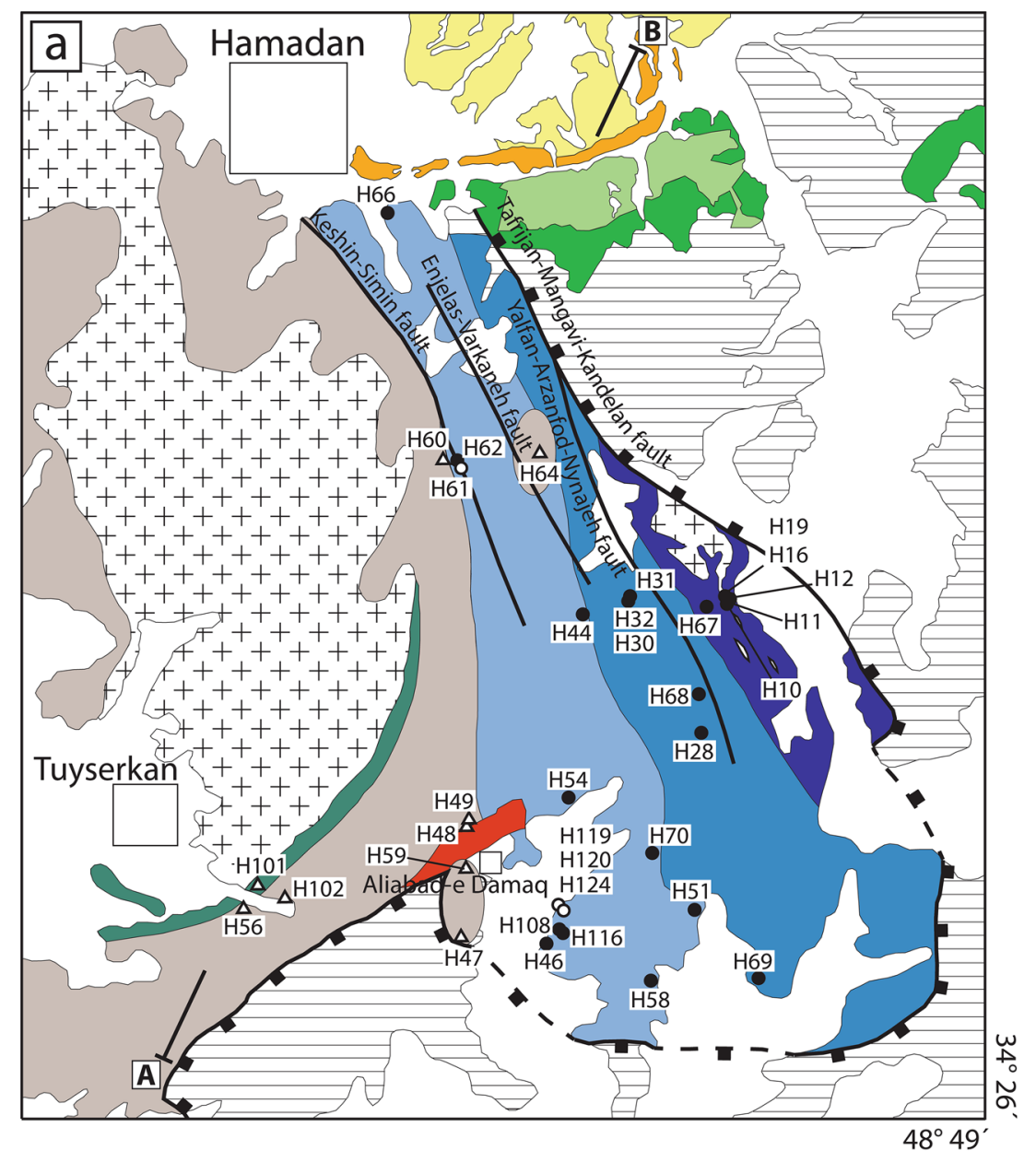

b

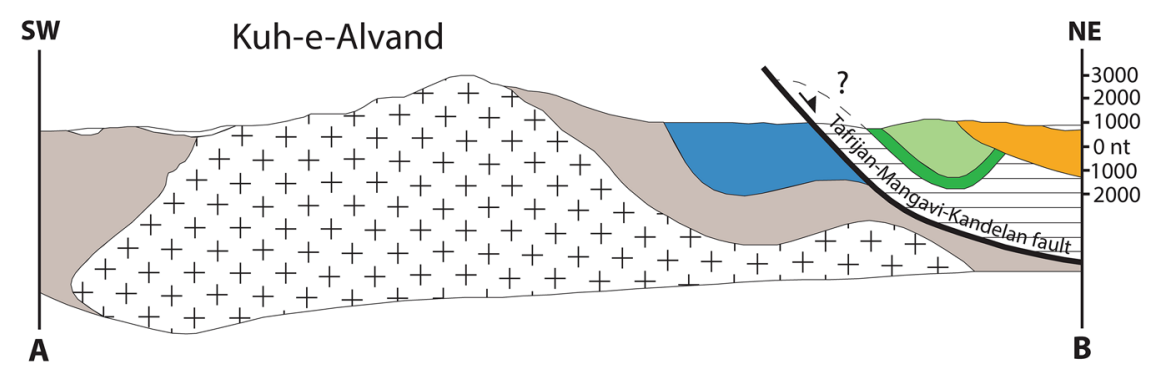

Fig. 2 Simplified geological map of the Hamadan metamorphic complex and Alvand composite pluton modified after Eghlimi (2000) and Baharifar et al. (2004). a A compilation showing the distribution of metapelitic zones and major faults in the Hamadan metamorphic complex. Sample numbers from east of the composite pluton are shown on the map. b Schematic cross section $(\mathrm{AB})$ through the
Hamadan region (after Sabzehei et al. 1977). Horizontal scale-vertical scale. c Map with tagged locality distribution of previous and new geochronological data. d Map with labelled previous and new $P-T$ estimates. The illustrated path from the contact is in agreement with Fig. 7 

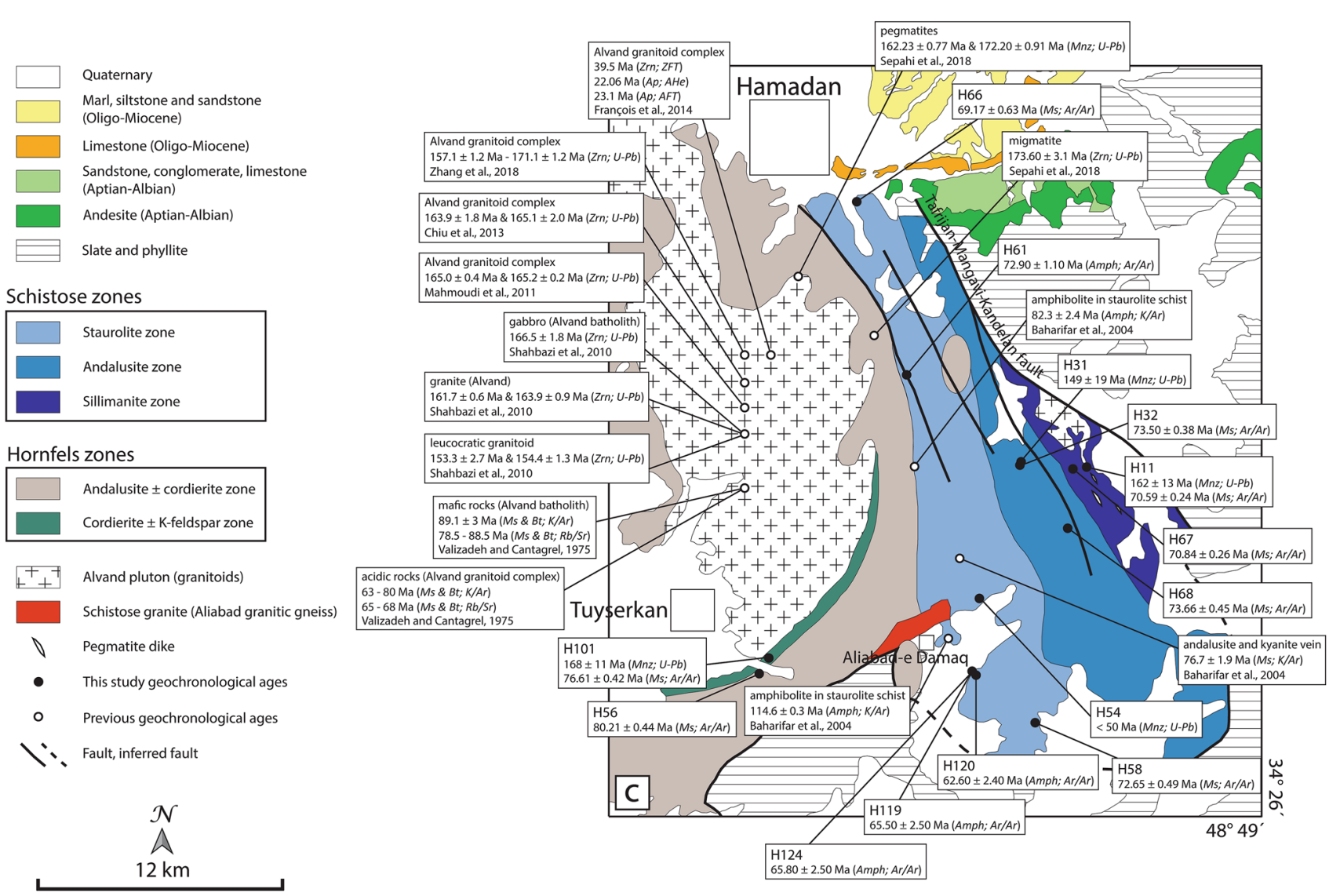

Fig. 2 (continued)

by andesitic lava and spilites, sandstones with conglomerates, marls and Orbitolina limestones of Aptian-Albian age (ca. 125-100.5 Ma; Cohen et al. 2013). Further on, we will refer to this structural unit as the "upper unit". The folded Aptian-Albian succession (Fig. 2a, b) is folded, cut by an angular unconformity and then overlain by continental Oligocene-Miocene sedimentary rocks. These structural relationships of low-grade metamorphic rocks and nonconformably overlying Aptian-Albian strata imply that in the low-grade part metamorphism ceased not later than Early Cretaceous (at ca. $125 \mathrm{Ma}$ ). Similar Lower Cretaceous cover successions were reported from several areas of the Sanandaj-Sirjan zone (Hassanzadeh and Wernicke 2016 and references therein).

The Alvand pluton is composite consisting of gabbroic rocks, granites, including mylonitized varieties, and leucocratic granitoids that occupy an area of $\sim 800 \mathrm{~km}^{2}$ (Shahbazi et al. 2010; Figs. 1, 2). A summary of existing age data from the Alvand composite pluton is compiled in Table 1 and shown on Fig. 2c. U-Pb zircon dating reveals that the Alvand composite pluton formed during the Jurassic between $171.1 \pm 1.2$ and $153.3 \pm 2.7 \mathrm{Ma}$ with the main intrusive phases between 166.5 and 163.9 Ma (Shahbazi et al. 2010; Mahmoudi et al. 2011; Chiu et al. 2013; Zhang et al. 2018). U-Pb monazite ages of pegmatites give ages between $172.20 \pm 0.91$ and $162.23 \pm 0.77 \mathrm{Ma}$ (Sepahi et al. 2018). The schistose Aliabad-e Damaq granitic gneiss yields an upper intercept age of 164.2 $\pm 5.4 \mathrm{Ma}$ (Shahbazi et al. 2010) and is included within schistose metapelites. Valizadeh and Cantagrel (1975) reported biotite and muscovite ages ranging from 68 to $104 \mathrm{Ma}(\mathrm{Rb}-\mathrm{Sr})$ and $68-89 \mathrm{Ma}$ $(\mathrm{K}-\mathrm{Ar}$ ) from the Alvand composite pluton indicating that the pluton was affected by a Cretaceous metamorphic event or cooled through ca. $425^{\circ} \mathrm{C}$, the Ar retention temperature of white mica.

The lower unit of the Hamadan metamorphic complex comprises variably deformed and metamorphosed pelitic, semipelitic and psammitic metasediments as well as quartzite, amphibolite and hornblende garben schists and some calc-silicate rocks (Baharifar et al. 2004; Sepahi et al. 2004). Fergusson et al. (2016) dated detrital zircons of an andalusite-garnet-biotite schist from the Hamadan Phyllite (lower unit) from a locality $35 \mathrm{~km}$ southeast of Hamadan and reported ${ }^{206} \mathrm{~Pb} /{ }^{238} \mathrm{U}$ ages of $270 \pm 12 \mathrm{Ma}$ for the youngest zircons. Consequently, the maximum depositional age of the Hamadan Phyllite is Middle Permian, which is 

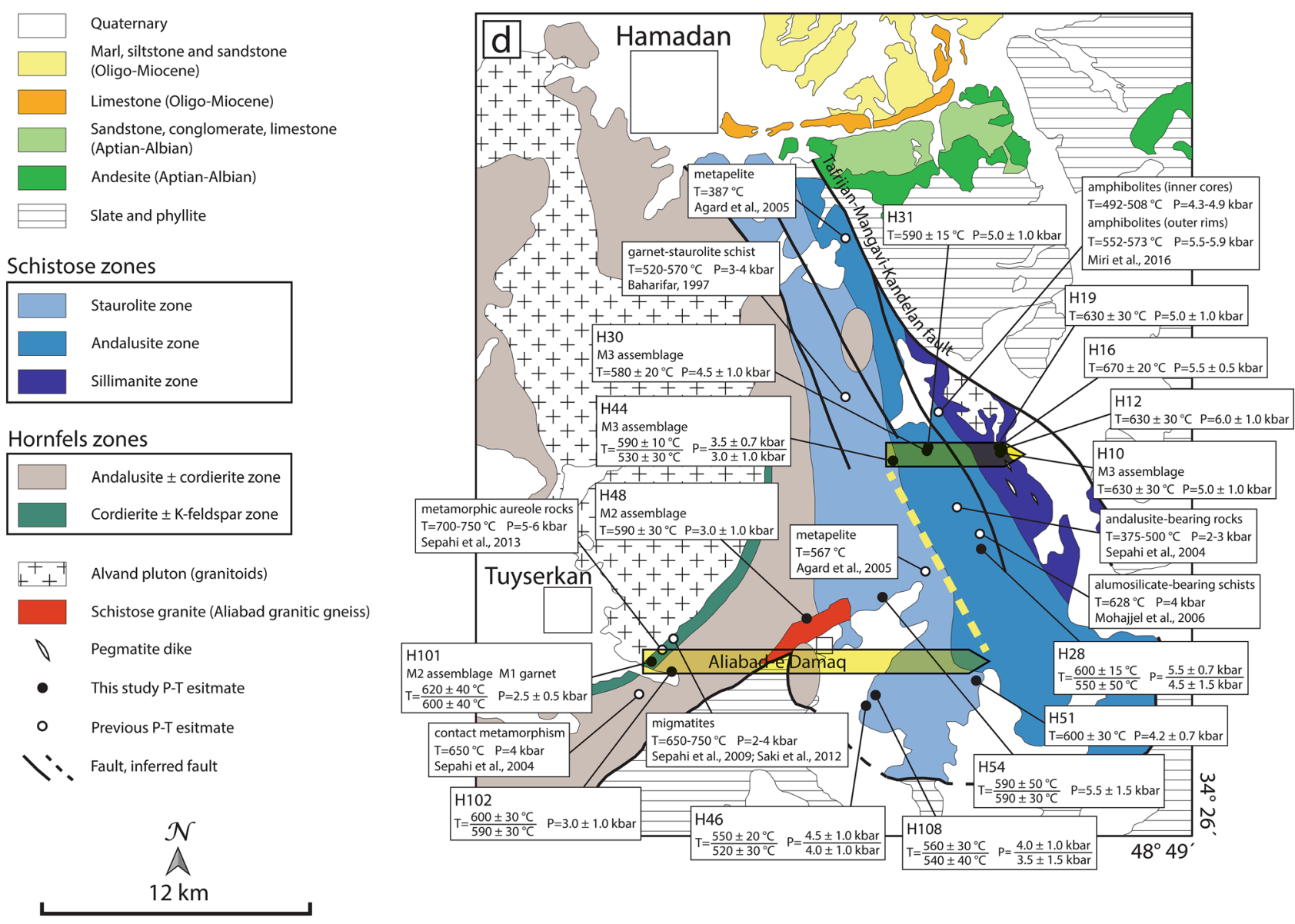

Fig. 2 (continued)

consistent with the presence of Triassic and Lower Jurassic fossils. A summary of existing age data from the Hamadan metamorphic complex is given in Table 1 and shown on Fig. 2c. In the high-grade lower unit of the Hamadan metamorphic complex, the timing of metamorphism is based on $\mathrm{K}-\mathrm{Ar}$ dating and gave three ages of $114.6 \pm 0.3 \mathrm{Ma}$ and $82.3 \pm 2.4 \mathrm{Ma}$ from amphibole in an amphibolite from the staurolite zone, and 76.7 $\pm 1.9 \mathrm{Ma}$ from muscovite of an andalusite-kyanite vein (Baharifar et al. 2004). Baharifar et al. (2004) proposed that the Hamadan complex was influenced by tectono-metamorphic events during the Jurassic to the mid-Cretaceous and by granitic intrusions in Late Cretaceous time although the Cretaceous granites were not verified by later studies. However, the subsequent determination of Jurassic (171-153 Ma) crystallization ages for the Alvand pluton and the large age range of almost 40 million years require a re-assessment of significance of these ages for the metamorphic evolution.
Andalusite \pm cordierite and cordierite $+\mathrm{K}$-feldspar hornfelses are exposed in close proximity to the Alvand composite pluton, whereas a large region of different, largely medium-grade metamorphic schists is exposed adjacent to the eastern/south-eastern part of the composite pluton (Sepahi et al. 2004; Agard et al. 2005). Field observation and textural evidence reveal that the hornfelses close to the Alvand granite grade into rocks with a schistose fabric further to the east. The flat-lying schistosity is coeval with recrystallization of a garnet + staurolite + biotite assemblage and refolded by an eastward-dipping crenulation schistosity (Agard et al. 2005). It is associated with a predominant NNW-SSE trending lineation (Agard et al. 2005), which turns to nearly E-W orientation in the region, where the schistose Aliabad-e Damaq granitic gneiss is exposed which probably represents a major apophyse of the Alvand composite pluton. 
Table 1 Summary of previous geochronological data related to metamorphism, subsequent cooling of metamorphic rocks and the granitic and gabbroic rocks of the Hamadan metamorphic complex

\begin{tabular}{|c|c|c|c|c|c|}
\hline Area & Rock type & Method & Dated mineral & Age \pm error $(\mathrm{Ma})$ & Authors \\
\hline \multirow{3}{*}{$\begin{array}{l}\text { Hamadan } \\
\text { meta- } \\
\text { morphic } \\
\text { complex }\end{array}$} & Andalusite and kyanite vein & $\mathrm{K} / \mathrm{Ar}$ & Muscovite & $76.7 \pm 1.9$ & \multirow[t]{3}{*}{ Baharifar et al. (2004) } \\
\hline & Amphibolite in staurolite schist & $\mathrm{K} / \mathrm{Ar}$ & Amphibole & $82.3 \pm 2.4$ & \\
\hline & Amphibolite in staurolite schist & $\mathrm{K} / \mathrm{Ar}$ & Amphibole & $114.6 \pm 0.3$ & \\
\hline \multirow{25}{*}{$\begin{array}{l}\text { Alvand } \\
\text { plutonic } \\
\text { complex }\end{array}$} & \multirow[t]{2}{*}{ Acidic rocks (Alvand granitoid complex) } & $\mathrm{K} / \mathrm{Ar}$ & Muscovite and biotite & $63-80$ & \multirow[t]{4}{*}{ Valizadeh and Cantagrel (1975) } \\
\hline & & $\mathrm{Rb} / \mathrm{Sr}$ & & $65-68$ & \\
\hline & \multirow[t]{2}{*}{ Mafic rocks } & $\mathrm{K} / \mathrm{Ar}$ & Muscovite and biotite & $89.1 \pm 3$ & \\
\hline & & $\mathrm{Rb} / \mathrm{Sr}$ & & $78.5-88.5$ & \\
\hline & Gabbro & ${ }^{206} \mathrm{~Pb} /{ }^{238} \mathrm{U}$ & Zircon & $166.5 \pm 1.8$ & \multirow[t]{5}{*}{ Shahbazi et al. (2010) } \\
\hline & \multirow[t]{2}{*}{ Granite (Alvand) } & ${ }^{206} \mathrm{~Pb} /{ }^{238} \mathrm{U}$ & Zircon & $163.9 \pm 0.9$ & \\
\hline & & ${ }^{206} \mathrm{~Pb} /{ }^{238} \mathrm{U}$ & Zircon & $161.7 \pm 0.6$ & \\
\hline & \multirow[t]{2}{*}{ Leucocratic granitoid } & ${ }^{206} \mathrm{~Pb} /{ }^{238} \mathrm{U}$ & Zircon & $154.4 \pm 1.3$ & \\
\hline & & ${ }^{206} \mathrm{~Pb} /{ }^{238} \mathrm{U}$ & Zircon & $153.3 \pm 2.7$ & \\
\hline & \multirow[t]{13}{*}{ Alvand granitoid complex } & ${ }^{206} \mathrm{~Pb} /{ }^{238} \mathrm{U}$ & Zircon & $165.2 \pm 0.2$ & \multirow[t]{2}{*}{ Mahmoudi et al. (2011) } \\
\hline & & ${ }^{206} \mathrm{~Pb} /{ }^{238} \mathrm{U}$ & Zircon & $165.0 \pm 0.4$ & \\
\hline & & ${ }^{206} \mathrm{~Pb} /{ }^{238} \mathrm{U}$ & Zircon & $165.1 \pm 2.0$ & \multirow[t]{2}{*}{ Chiu et al. (2013) } \\
\hline & & ${ }^{206} \mathrm{~Pb} /{ }^{238} \mathrm{U}$ & Zircon & $163.9 \pm 1.8$ & \\
\hline & & ZFT & Zircon & 39.5 & \multirow[t]{3}{*}{ François et al. (2014) } \\
\hline & & $\mathrm{AHe}$ & Apatite & 22.06 & \\
\hline & & AFT & Apatite & 23.1 & \\
\hline & & ${ }^{206} \mathrm{~Pb} /{ }^{238} \mathrm{U}$ & Zircon & $157.1 \pm 1.2$ & \multirow[t]{6}{*}{ Zhang et al. (2018) } \\
\hline & & ${ }^{206} \mathrm{~Pb} /{ }^{238} \mathrm{U}$ & Zircon & $167.7 \pm 1.5$ & \\
\hline & & ${ }^{206} \mathrm{~Pb} /{ }^{238} \mathrm{U}$ & Zircon & $171.1 \pm 1.2$ & \\
\hline & & ${ }^{206} \mathrm{~Pb} /{ }^{238} \mathrm{U}$ & Zircon & $159.3 \pm 1.0$ & \\
\hline & & ${ }^{206} \mathrm{~Pb} /{ }^{238} \mathrm{U}$ & Zircon & $167.2 \pm 1.3$ & \\
\hline & & ${ }^{206} \mathrm{~Pb} /{ }^{238} \mathrm{U}$ & Zircon & $167.3 \pm 2.7$ & \\
\hline & \multirow[t]{2}{*}{ Pegmatites } & ${ }^{206} \mathrm{~Pb} /{ }^{238} \mathrm{U}$ & Monazite & $162.23 \pm 0.77$ & \multirow[t]{2}{*}{ Sepahi et al. (2018) } \\
\hline & & ${ }^{206} \mathrm{~Pb} /{ }^{238} \mathrm{U}$ & Monazite & $172.20 \pm 0.91$ & \\
\hline & Migmatite & ${ }^{206} \mathrm{~Pb} /{ }^{238} \mathrm{U}$ & Zircon & $173.60 \pm 3.1$ & Sepahi et al. (2019) \\
\hline
\end{tabular}

\section{Previous $P$ - $T$ estimates}

Sepahi et al. (2004) defined two possible clockwise $P-T$ paths that suggest peak metamorphic conditions of up to $650{ }^{\circ} \mathrm{C}$ at $4 \mathrm{kbar}$ in the high-grade metamorphic lower unit of the Hamadan region. Based on Raman spectroscopy of graphitic material, Agard et al. (2005) demonstrated temperatures ranging from $387 \pm 9$ to $567 \pm 33{ }^{\circ} \mathrm{C}$. Mohajjel et al. (2006) proposed two main metamorphic events in alumosilicate-bearing schists accompanied by deformation episodes based on mineral assemblages and thermobarometry. The results indicate that $P-T$ conditions during the second phase of prograde metamorphism reached a maximum of about $630{ }^{\circ} \mathrm{C}$ at a pressure of $4 \mathrm{kbar}$. The first event presented by Mohajjel et al. (2006) pertains to oblique subduction of the Neotethys oceanic crust in Late Jurassic to Early Cretaceous times, and the second stage is the Late Cretaceous event synchronous with the main magmatism that increased the thermal gradient while sillimanite formed. However, no supporting age data for the proposed Late Cretaceous metamorphic event are available. Sepahi et al. (2009) and Saki et al. (2012) calculated peak metamorphic conditions of $\sim 650-750{ }^{\circ} \mathrm{C}$ and $\sim 2-4 \mathrm{kbar}$ by means of conventional thermobarometry methods in migmatites occurring adjacent to the Alvand composite pluton. Maximum $P-T$ conditions of $700-750{ }^{\circ} \mathrm{C}$ at $5-6$ kbars were recently presented for the high-grade metamorphic mafic rocks from the metamorphic aureole around the pluton (Sepahi et al. 2013). Based on amphibole composition and hornblende-plagioclase thermometry, thermobarometric calculations of Miri et al. (2016) provided $P-T$ conditions of $492-508{ }^{\circ} \mathrm{C}$ and 4.3-4.9 kbar for the cores of these minerals and $552-573{ }^{\circ} \mathrm{C}$ and 5.5-5.9 kbar for the outer rims, respectively. Considering the methodological uncertainties in pressure $( \pm 1.2 \mathrm{kbar})$ 
and temperature $\left( \pm 37^{\circ} \mathrm{C}\right)$ determinations, Miri et al. (2016) inferred an isobaric temperature increase related to thermal perturbation associated with Late Jurassic magmatism. Recently, Sepahi et al. (2019) described migmatites along the northeastern part of the contact between the Alvand composite pluton and the Hamadan metamorphic complex. These authors determined $P-T$ conditions of $640-700{ }^{\circ} \mathrm{C}$ and 3-5 kbar for migmatization, which was dated at ca. $170 \mathrm{Ma}$ using the $\mathrm{U}-\mathrm{Pb}$ zircon technique. These results point to a causal link between the magmatic activity and the migmatization. A summary of existing $P-T$ estimates from the Hamadan complex is given in Table 2 and Fig. 2 d.

\section{Petrography}

We collected and prepared thin sections of more than 100 samples from different metamorphic zones within the Hamadan complex for petrographic studies. The metamorphic units east of the Alvand composite pluton can be texturally divided into two main zones: (1) an approximately $4-5 \mathrm{~km}$ wide hornfels zone, extending from the contact of the pluton with the first appearance of spots of large cordierite to the last occurrence of cordierite in andalusite-cordierite hornfels; (2) a schistose zone comprising staurolite-bearing schists. This zone is followed outward up to about $15 \mathrm{~km}$ distance from the contact by rocks with abundant porphyroblasts of andalusite and an area marked by sillimanite replacing andalusite. The metapelitic rocks are locally interlayered with minor amphibolite. Based on the studied samples, we distinguish three stages of metamorphism from textural and deformational points of view:

(1) Relics of a first metamorphic stage (M1) are preserved as garnet inclusions in cordierite, which occur only within the hornfels zone. These garnets also include fine-grained feldspar and chlorite of a lower grade metamorphic stage, which are interpreted as early remnants of the M1 metamorphism (Fig. 3b).
(2) The contact metamorphic (hornfels) zones (M2) are not only characterized by typical porphyroblasts like cordierite but also contain boudinaged pegmatite dikes surrounded by a weak foliation in the pelitic country rocks (Fig. 3a, f, g) indicating a gradual transition between the contact metamorphic zones (M2) to schistose zones dominated by M3 mineral assemblages.

(3) In the east, the schistose zones include also the Aliabade Damaq granite gneiss, which has a similar age as the Alvand composite pluton. The area is characterized by a penetrative foliation and a NNW-SSE to N-S trending mineral and stretching lineation, which is folded by later deformation stages (Agard et al. 2005; Mohajjel et al. 2006). In the southeast, the stretching lineation is ca. E-W subparallel to the trend of the schistose Aliabad-e Damaq granite gneiss.

In the following, we use these textural relationships to distinguish between mineral assemblages related to the M1, M2 and M3 metamorphic stages. Based on a suitable mineralogy, textures and lack of alteration, we examined several samples from the whole metamorphic area for thermobarometry. A list of selected samples investigated in detail is presented in Table 3. Four samples were selected for chemical $\mathrm{U}-\mathrm{Th}-\mathrm{Pb}$ monazite dating and 12 samples from all units of the Hamadan metamorphic complex were selected for ${ }^{40} \mathrm{Ar} /{ }^{39} \mathrm{Ar}$ dating of muscovite and amphibole. Their geographical locations and mineral assemblages are given in Table 3 and Fig. 2a.

All mineral assemblages contain monazite and zircon, and most contain garnet, muscovite, biotite, plagioclase and quartz. Graphite and ilmenite are present in low amounts in all samples. Chlorite and fine-grained white mica ("sericite") are mostly present as secondary retrograde phases. In the following, we describe the zones from the contact outward. The reactions are discussed in the text according to the numbering scheme in Table 6 and Fig. 10.
Table 2 A summary of existing $P-T$ estimates from the Hamadan metamorphic complex

\begin{tabular}{llll}
\hline Rock type & $T\left({ }^{\circ} \mathrm{C}\right)$ & $P(\mathrm{kbar})$ & Authors \\
\hline Garnet-staurolite schist & $520-570$ & $3-4$ & Baharifar (1997) \\
Low-grade andalusite-bearing rocks & $375-500$ & $2-3$ & Sepahi et al. (2004) \\
Contact metamorphism & 650 & 4 & Sepahi et al. (2004) \\
Metapelite & $387-567$ & - & Agard et al. (2005) \\
Aluminosilicate-bearing schists & 628 & 4 & Mohajjel et al. (2006) \\
Migmatites & $650-750$ & $2-4$ & Sepahi et al. (2009) and Saki et al. (2012) \\
Metamorphic aureole rocks & $700-750$ & $5-6$ & Sepahi et al. (2013) \\
Amphibolites (inner cores) & $492-508$ & $4.3-4.9$ & Miri et al. (2016) \\
Amphibolites (outer rims) & $552-573$ & $5.5-5.9$ & Miri et al. (2016) \\
\hline
\end{tabular}




\section{Hornfels zones}

\section{Cordierite + K-feldspar zone}

The cordierite $+\mathrm{K}$-feldspar zone forms only a narrow band close to the Alvand composite pluton (Fig. 2). The pelitic hornfels samples were taken within $<1 \mathrm{~km}$ from the Alvand granite and display the mineral assemblage $\mathrm{Crd}+\mathrm{Kfs}+\mathrm{Bt}+\mathrm{Grt}+\mathrm{Pl}+\mathrm{Qtz}$ (mineral abbreviations are according to Kretz 1983). Close to the contact, the samples contain large well-preserved cordierite, rare small garnet and no andalusite or relics thereof. Pegmatite dikes boudinaged by brittle faults are surrounded by a weakly developed foliation. The rocks develop prominent "spots" (up to $\sim 2 \mathrm{~cm}$ in size; Fig. 3a-c), corresponding to anhedral and roughly ovoid, inclusion-rich cordierite poikiloblasts, which are set in a fine-grained granoblastic matrix of feldspar, biotite, muscovite, quartz and ilmenite. The development of $\mathrm{K}$-feldspar that occurs in anhedral, cryptoperthitic grains associated with quartz and the paucity of muscovite at the highest grade close to the contact may be representative of leucosome development by partial melting.

The peak metamorphic conditions of $620 \pm 40{ }^{\circ} \mathrm{C}$ and $2.5 \pm 0.5$ kbar obtained in sample H101 (for details, see below) are just below the wet granite solidus, but minor dehydration melting could have occurred by muscovite (Fig. 3d) dehydration and associated release of a hydrous fluid:

$\mathrm{Ms}+\mathrm{Qtz}=\mathrm{Kfs}+\mathrm{And}+\mathrm{H}_{2} \mathrm{O}$ (reaction \#3)

Garnet occurs as euhedral and rarely fractured and cracked crystals, within the matrix and in some cases as inclusions in cordierite (Fig. 3b). The garnet inclusions are interpreted to be of an early-stage origin (M1), predating the growth of cordierite, assuming that cordierite growth is due to the heat from the intrusion. The euhedral garnets from the matrix are in equilibrium with cordierite and thus considered to be part of the hornfels stage (M2).

\section{Andalusite \pm cordierite zone}

Following the narrow cordierite $+\mathrm{K}$-feldspar zone, a 1-5 km wide And \pm Crd zone extends outwards from the contact with the pluton (Fig. 2). In this zone, metapelitic rocks mainly have a hornfelsic texture, a dark greyish colour (Fig. 3e) and typically contain the assemblage And $\pm \mathrm{Crd} \pm \mathrm{Kfs} \pm \mathrm{Grt} \pm \mathrm{M}$ $\mathrm{s}+\mathrm{Bt}+\mathrm{Pl}+\mathrm{Qtz}$. Andalusite generally forms well-preserved, idioblastic, inclusion-poor crystals that occur in the matrix (Fig. 3e-g). Cordierite occurs as ellipsoidal, inclusion-filled anhedral poikiloblasts with biotite and a low amount of muscovite in the matrix. A weak foliation is observed in some samples (Fig. 3f, g). The zone is also marked by the existence of K-feldspar in some, but not all rocks. In the outer parts of the andalusite \pm cordierite zone, cordierite is gradually replaced by fine-grained aggregates rich in chlorite and quartz while chiastolitic andalusite is present as large $\mathrm{cm}$-sized idiomorphic blasts with accumulations of graphite/ opaque phases as inclusions and along its rectilinear grain edges (Fig. 3g). As a whole, with increasing proximity to the composite pluton, the proportion of andalusite decreases and cordierite as well as K-feldspar crystals become larger and more abundant. A possible reaction that involves And as reactant and is forming $\mathrm{Crd}+\mathrm{Kfs}$ is as follows:

$\mathrm{Bt}+\mathrm{And}+\mathrm{Qtz}=\mathrm{Crd}+\mathrm{Kfs}+\mathrm{H}_{2} \mathrm{O}$ (reaction \#4)

The garnets are present mostly as euhedral, partly fractured crystals and are considered to belong to the M2 metamorphic assemblage (Fig. 3h). In contrast M1 garnet is only found in the hornfels zone and occurs as relics enclosed by cordierite.

\section{Schistose zones}

\section{Staurolite zone}

Further to the east, the staurolite zone follows the hornfels zone (Fig. 2). The dominant mineral assemblage in this zone contains $\mathrm{Grt}+\mathrm{St}+\mathrm{Bt}+\mathrm{Ms}+\mathrm{Pl}+\mathrm{Qtz}$. The rocks are predominantly fine-grained, well-foliated schists (Fig. 4a, b), which display a typical S-C shear fabric.

Staurolite displays a pre- to syn-deformational fabric and is seen as euhedral to subhedral porphyroblasts up to $\sim 3 \mathrm{~cm}$ length, or as small $(\sim 1 \mathrm{~mm})$ blocky crystals generally replaced by chlorite at the rim (Fig. 4c, d). Some rare staurolite grains seem to exhibit two stages of growth with an earlier growth phase defined by trails of inclusions, followed by an inclusion-poor rim with $\sim 2 \mathrm{~mm}$ thickness (Fig. $4 \mathrm{~d}$ ). The staurolite growth postdates partly the garnet growth since small idioblastic garnet grains occur as inclusions within them (Fig. 4c). The inclusions in the staurolite are parallel to foliation and indicate syn-deformative growth (Fig. 4d).

Garnet is nearly ubiquitous and locally occurs as perfect idiomorphic crystal up to $\sim 6 \mathrm{~mm}$ in diameter. Texturally, garnet mostly has a pre- to syn-deformative origin in all schistose metamorphic zones (Fig. 4e). Garnet grains contain quartz, graphite and ilmenite inclusions and typically appear euhedral to subhedral in shape, although corners and edges of crystals show typical retrograde features such 

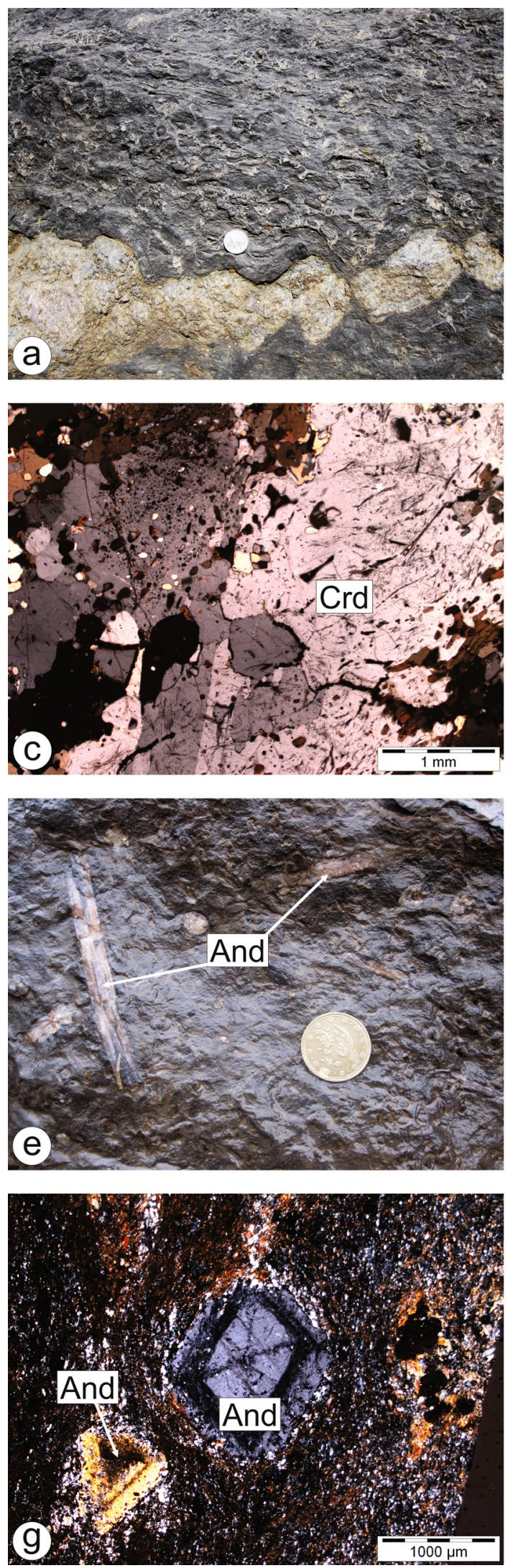
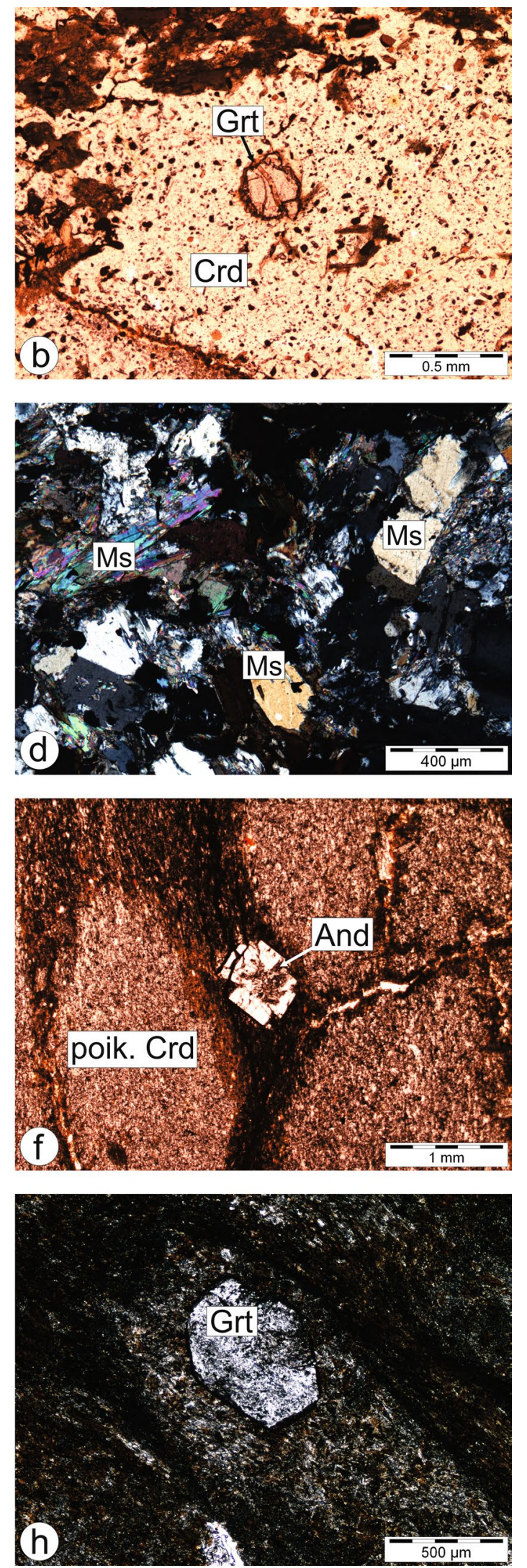
4Fig. 3 Photomicrographs and photographs showing the mineral assemblages and hornfelsic textures of cordierite $+\mathrm{K}$-feldspar (a-d) and andalusite \pm cordierite (e-h) zones. a The pelitic hornfels with a boudinaged pegmatite. Note a weak foliation in the hornfels and some small fringes around andalusite porhyroblasts parallel to the weak foliation. b, c Large cordierite poikiloblasts containing small garnet inclusions. d The occurrence of muscovite in the high-grade hornfels zone close to the contact aureole. $\mathbf{e}-\mathbf{g}$ Fresh andalusite porphyroblasts is present in a fine-grained matrix. $\mathbf{f}$ Cordierite is replaced by finegrained aggregates rich in chlorite and quartz. Note weak foliation overgrown by cordierite porphyroblast in $\mathbf{f}$ and $\mathbf{g}$. $\mathbf{h}$ Garnet occurs as euhedral crystal in the matrix. Mineral abbreviations are according to Kretz (1983)

as rounding and partial replacement by biotite and chlorite (Fig. 4e). Biotite, muscovite and chlorite form tiny flakes, in preferred orientation defining the foliation. Some biotite grains have been replaced by secondary chlorite (Fig. 4e).

Hornblende garbenschist and amphibolite interlayers within metapelites of the staurolite zone mainly contain acicular and euhedral amphibole, and garnet in a finegrained matrix of quartz, plagioclase, K-feldspar and the accessories titanite, epidote and clinozoisite.

\section{Andalusite zone}

A large area of metapelitic schists adjacent to the staurolite zone displays the assemblage And $\pm \mathrm{St}+\mathrm{Grt}+\mathrm{Bt}+\mathrm{Ms}+\mathrm{C}$ $\mathrm{hl}+\mathrm{Pl}+\mathrm{Qtz}$ (Fig. 2). The andalusite porphyroblasts are up to $\sim 10 \mathrm{~cm}$ in length (Fig. $4 \mathrm{~g}$ ) and typically display a chiastolitic cruciform pattern of inclusions and accumulations of graphite and opaque phases along rectilinear grain edges (Fig. 4h). Andalusite is slightly altered to fine- to coarsegrained "sericite"; however, generally well-preserved, idioblastic, inclusion-poor crystals are observed, too.

In samples, in which andalusite is present in larger amounts, muscovite reacted with staurolite to form andalusite according to the following equation (Fig. 4i, j):

$\mathrm{Ms}+\mathrm{St}+\mathrm{Qtz}=\mathrm{And}+\mathrm{Bt}+\mathrm{H}_{2} \mathrm{O} \quad$ (reaction \#6).

Textural evidence indicates that staurolite growth preceded andalusite growth in some cases, while andalusite is randomly pre- and syn-deformative. Some staurolite appears as poikiloblasts with sigmoidal inclusion trails reflecting syn-deformative growth as well (Mohajjel et al. 2006; Fig. 4k).

Garnet frequently occurs as up to $\sim 3 \mathrm{~mm}$ large porphyroblasts and few of them occur as euhedral to subhedral inclusions in andalusite (Fig. 4h), suggesting that garnet predates the growth of andalusite while in other places garnet is surrounded by the mica matrix (Fig. 41). Some garnets developed poikilitic grains with inclusions of quartz, graphite and ilmenite (Fig. 4m).

\section{Sillimanite zone}

The onset of the sillimanite zone (Fig. 2), is marked by the appearance of fibrolite and rare fine-grained prismatic sillimanite replacing andalusite. The diagnostic assemblage of this zone is $\mathrm{Sil} \pm \mathrm{And}+\mathrm{Grt}+\mathrm{Bt}+\mathrm{Ms}+\mathrm{Qtz}+\mathrm{Pl}$. In this zone, no signs of coexisting K-feldspar and sillimanite or the development of migmatization is observed.

Sillimanite typically occurs in mats within the matrix and as fine needles intergrown with andalusite or coarse muscovite (Fig. 4n, o), postdating the growth of andalusite (Agard et al. 2005). Garnet grains are commonly scattered throughout the assemblage. Locally, sillimanite, staurolite and tourmaline are observed in shear bands in this zone (Agard et al. 2005).

\section{Schistose granite gneiss of Aliabad-e Damaq}

The Jurassic granite gneiss of Aliabad-e Damaq shows a schistose fabric composed of biotite and subordinate white mica, deformed K-feldspar (mostly microcline) and wellrecrystallized plagioclase. Quartz shows grain boundary migration recrystallization (Fig. 4f), which typically forms close to amphibolite facies-grade deformation (at ca. $500{ }^{\circ} \mathrm{C}$ according to Stipp et al. 2002).

\section{Analytical techniques}

The analytical techniques are described in the Appendix. These include the following: whole rock geochemical analyses of metapelitic rocks, mineral chemical compositions determined by scanning electron microscope (EDX and WDX spectrometer), Th-U-Pb monazite dating by electron microprobe and ${ }^{40} \mathrm{Ar} /{ }^{39} \mathrm{Ar}$ dating of amphibole and white mica.

\section{Mineral chemistry}

For garnet profiles, the largest grains were used since we confirmed they represent cuts through the centre of the garnet grain. Nearly all schist samples contain compositionally zoned garnet with dominantly almandine (62-82\%), spessartine (2-23\%), minor pyrope (4-15\%) and subordinate grossular (1-10\%) (Table 4; Fig. 5). Only garnet from the hornfels zone displays a homogeneous compositional zoning pattern indicating growth at constant $P-T$ conditions (Fig. 5a). Garnet compositional profiles of schistose zones generally depict a rising trend in $X_{\text {alm }}$ and a decrease in $X_{\text {sps }}$ from core-to-rim. $X_{\text {grs }}$ and $X_{\text {prp }}$ display mostly smoothly varying compositional trends (Fig. $5 b-d$ ). These patterns are interpreted as typical trends for prograde garnet growth in metapelites. 


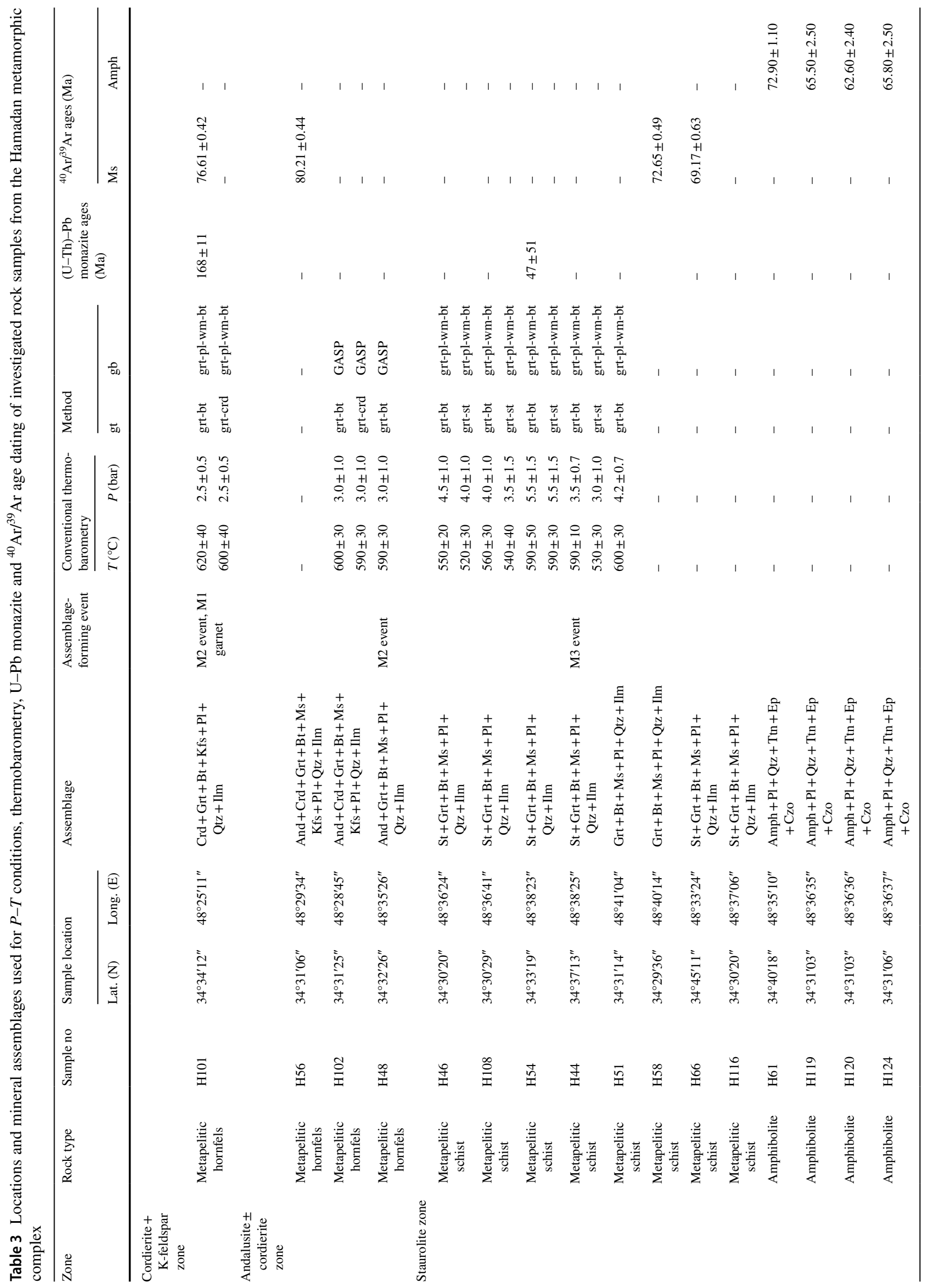




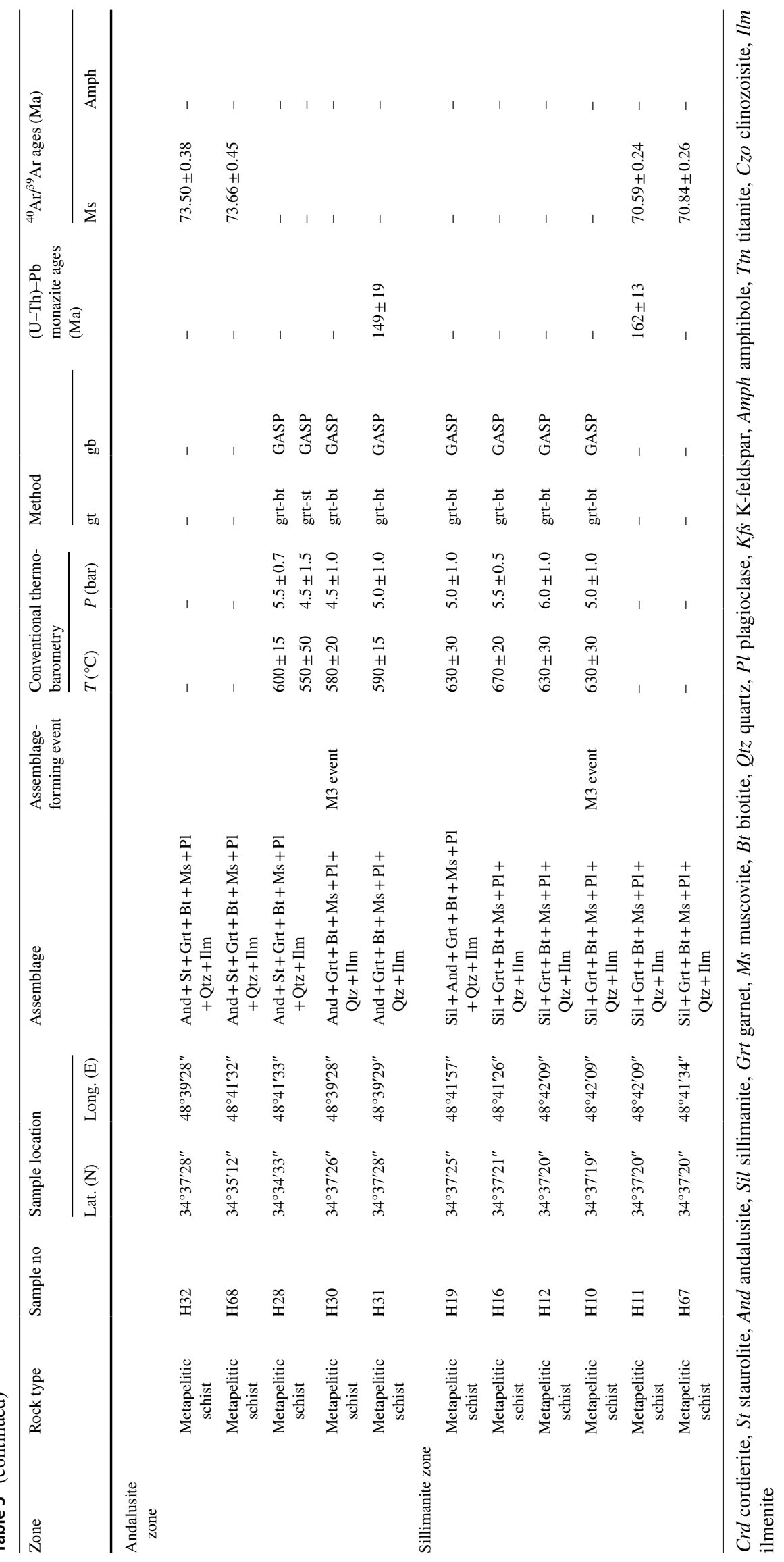


In samples from both the hornfels and schistose zones, the minerals within the matrix show only a small compositional variation or are chemically homogeneous. Cordierite is characterized by a minor variation in $X_{\mathrm{Mg}}$ ranging from 0.43 to 0.50 (Table 4). Biotite is characterized by $\mathrm{Al}^{\mathrm{VI}}$, and Ti contents in the range of $0.27-0.43$ and $0.06-0.21$ a.p.f.u in the hornfels zones and in the range of $0.38-0.67$ and $0.07-0.18$ a.p.f.u in the schistose zones, respectively. $X_{\mathrm{Mg}}$ of biotite varies between 0.35 and 0.51 in the hornfels zones and 0.38 and 0.55 in the schistose zones. The F content of biotite is around $0.5 \mathrm{wt} \%$ for nearly all selected samples (Table 4).

Plagioclase in the hornfels zones ranges in composition from almost pure albite $\mathrm{Ab}_{91} \mathrm{An}_{7} \mathrm{Or}_{0}$ to andesine $\mathrm{Ab}_{69} \mathrm{An}_{31} \mathrm{Or}_{0}$. In schistose zone rocks, plagioclase varies from albite $\mathrm{Ab}_{87} \mathrm{An}_{13} \mathrm{Or}_{0}$ to andesine $\mathrm{Ab}_{56} \mathrm{An}_{43} \mathrm{Or}_{0}$ (Table 4). Alkali feldspar is orthoclase $\mathrm{Ab}_{10} \mathrm{Or}_{89} \mathrm{An}_{0}$ in the hornfels zones. The chemical variations reported here are not related to zoning but differ from sample to sample.

Muscovite has Si-contents ranging from 3.01 to 3.15 a.p.f.u in the hornfels zones, while these contents vary from 3.01 to 3.23 a.p.f.u. in the schistose zones. The $\mathrm{K} /(\mathrm{K}+\mathrm{Na})$ ratio of muscovite is $0.94-0.96$ in the hornfels zones and 0.81-0.93 in the schistose zones (Table 4).

Finally, the chemistry of staurolite does not show systematic trends in the variation of $X_{\mathrm{Fe}}(0.77-0.89)$ and $\mathrm{ZnO}$ contents (up to $0.71 \mathrm{wt} \%$ ) (Table 4). Although two generations of staurolite can be distinguished in the staurolite zone, no significant chemical difference can be found.

\section{$\boldsymbol{P}-\boldsymbol{T}$ determinations}

$P-T$ conditions of metamorphism were obtained using conventional geothermobarometry as well as equilibrium assemblage diagrams.

\section{Conventional thermobarometry}

For conventional thermobarometry the PET1.1 software (Dachs 1998, 2004) was used. Appropriate matrix mineral compositions, which are in equilibrium with each other and occur also in "domains" near garnet, were selected for calculation of pressure and temperature conditions (Table 3).

\section{Hornfels unit}

The Grt-Bt (Holdaway 2000) and Grt-Crd geothermometers coupled with the GASP (Koziol 1989) and Grt-Pl-Ms-Bt (Hoisch 1990; Wu 2015) geobarometers were applied for assemblages from the cordierite $+\mathrm{K}$-feldspar and andalusite \pm cordierite zones to calculate peak metamorphic temperatures of $620 \pm 40{ }^{\circ} \mathrm{C}$ and $590 \pm 30^{\circ} \mathrm{C}$, respectively (Table 3; Figs. 2d, 6a). In both samples, the pressure remains
Fig. 4 Photomicrographs, field photographs and back-scattered electron image of schistose rocks in the staurolite $(\mathbf{a}-\mathbf{e})$, andalusite $\left(\mathbf{g}_{-}\right.$ m) and sillimanite (n-o) zones. a, b garnet-staurolite bearing rocks are well-foliated schists which show a typical crenulation fabric. c, h Garnet crystals occur as inclusions in staurolite and andalusite. d Staurolite grain seem to show two stages of growth with the staurolite growth phase defined by trails of inclusions, followed by an inclusion-poor rim in staurolite-bearing rocks. Note chloritization of staurolite. e Biotite grains have been replaced by secondary chlorite in pressure fringes around garnet porphyroblasts. f Photomicrograph representing the foliation with grain boundary bulging of the schistose Jurassic granite gneiss of Aliabad-e Damaq. $\mathbf{g}$, $\mathbf{h}$ Large andalusite porphyroblasts are typically present a chiastolitic cruciform pattern of inclusions and accumulations of graphite and opaque phases along rectilinear grain-edges. i Andalusite largely grew by replacement of muscovite. j Partial replacement of staurolite by andalusite. $\mathbf{k}$ Staurolite poikiloblast presenting sigmoidal inclusion trails reflecting syn-deformative growth in andalusite-staurolite bearing rocks. $\mathbf{l}$ Microfabric of white mica in equilibrium with garnet. $\mathbf{m}$ Garnet is developed as poikilitic grains with inclusions of quartz, graphite and ilmenite. n, o Sillimanite occurs in mats within the matrix and as fine needles intergrown with andalusite or coarse muscovite. Mineral abbreviations are according to Kretz (1983)

constant at around $\sim 3.0 \pm 1.0 \mathrm{kbar}$. The average temperature increases towards the pluton.

\section{Schistose unit}

Mineral assemblages belonging to the staurolite zone yield peak $P-T$ conditions of $590 \pm 50^{\circ} \mathrm{C}$ and $5.5 \pm 1.5 \mathrm{kbar}$ based on Grt-Bt (Holdaway 2000) and Grt-St (Perchuk 1969) thermometers and the Grt-Pl-Ms-Bt barometer (Table 3; Figs. 2d, 6b). The Grt-Bt and Grt-St thermometers in combination with the GASP barometer were applied for assemblages from the andalusite zone, yielding values around $600 \pm 15{ }^{\circ} \mathrm{C}$ and $5.5 \pm 0.7$ kbar (Table 3; Figs. $2 \mathrm{~d}, 6 \mathrm{~b}$ ). Finally, the Grt-Bt thermometer and the GASP barometer applied for the sillimanite zone show values of $670 \pm 20^{\circ} \mathrm{C}$ and $5.5 \pm 0.5 \mathrm{kbar}$ (Table 3; Figs. $2 \mathrm{~d}, 6 \mathrm{~b}$ ). $P-T$ results appear to exhibit a small decrease in temperature from cordieritebearing rocks to andalusite-bearing rocks in the hornfels unit and a small increase from staurolite-bearing rocks towards the andalusite- and sillimanite-bearing rocks in schistose zones (Fig. 7). A minor increase in pressure from the contact outwards is also observed (Fig. 6).

\section{Assemblage stability diagrams}

Equilibrium assemblage diagrams were constructed in the chemical system $\mathrm{MnO}-\mathrm{Na}_{2} \mathrm{O}-\mathrm{CaO}-\mathrm{K}_{2} \mathrm{O}-\mathrm{FeO}-\mathrm{MgO}-\mathrm{Al}_{2} \mathrm{O}$ ${ }_{3}-\mathrm{SiO}_{2}-\mathrm{H}_{2} \mathrm{O}-\mathrm{TiO}_{2}$ using the THERIAK/DOMINO software package from 03.01.2012 (de Capitani and Brown 1987; de Capitani and Petrakakis 2010) in conjunction with the thermodynamic database of Holland and Powell (1998), updated to dataset 5.5 in 2003 that incorporates the $\mathrm{Al}_{2} \mathrm{SiO}_{5}$ triple 

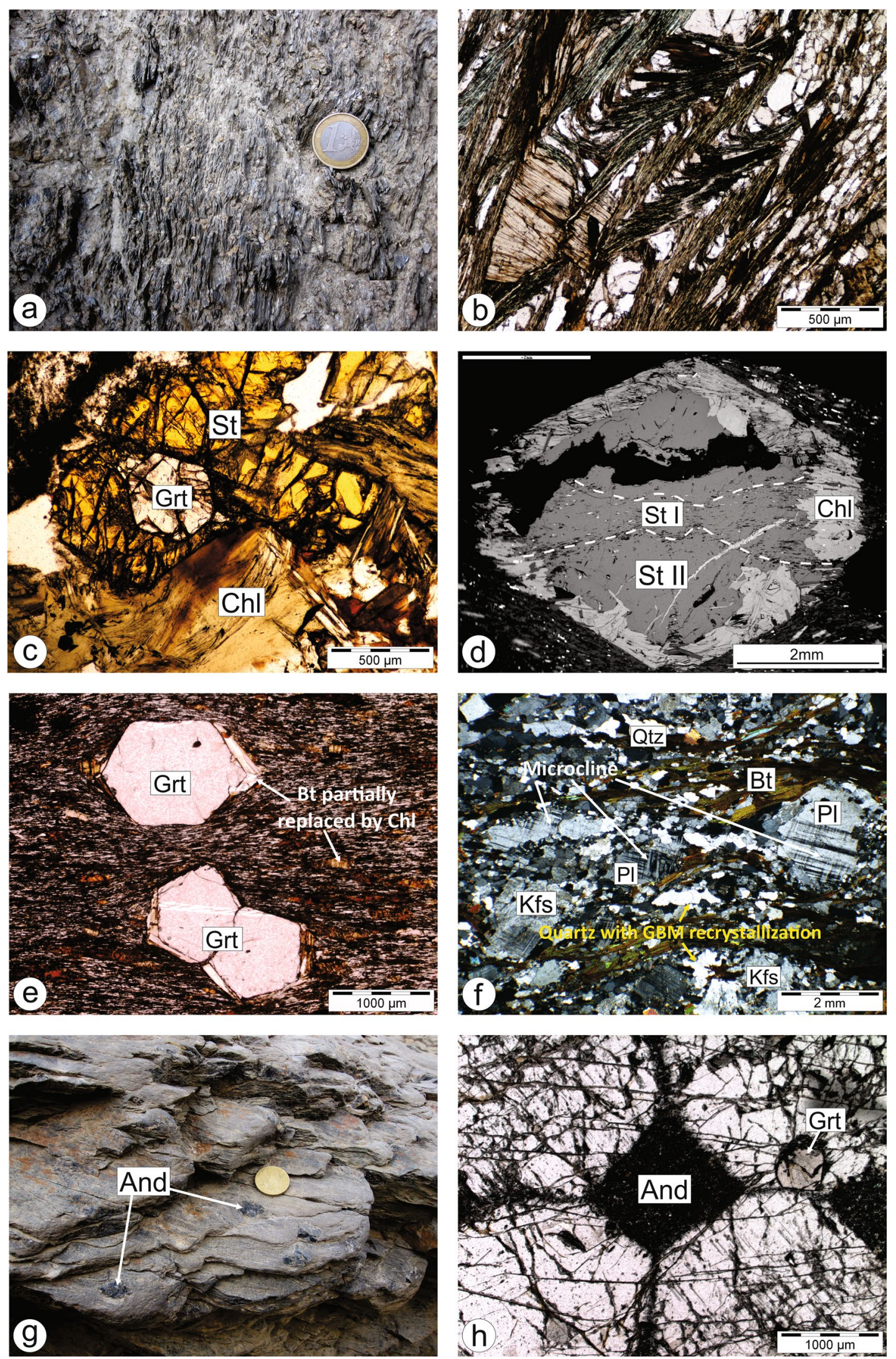

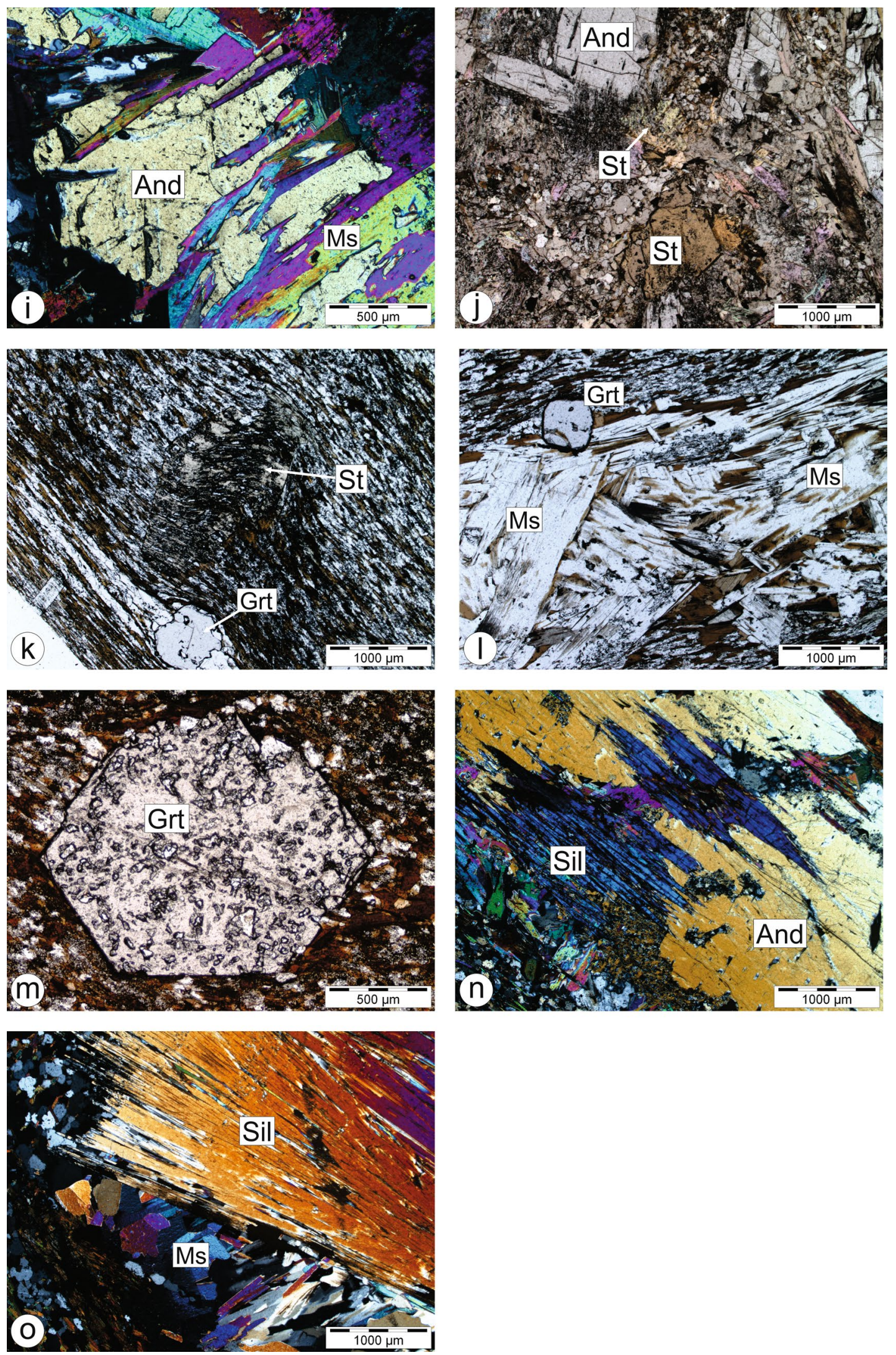

Fig. 4 (continued) 


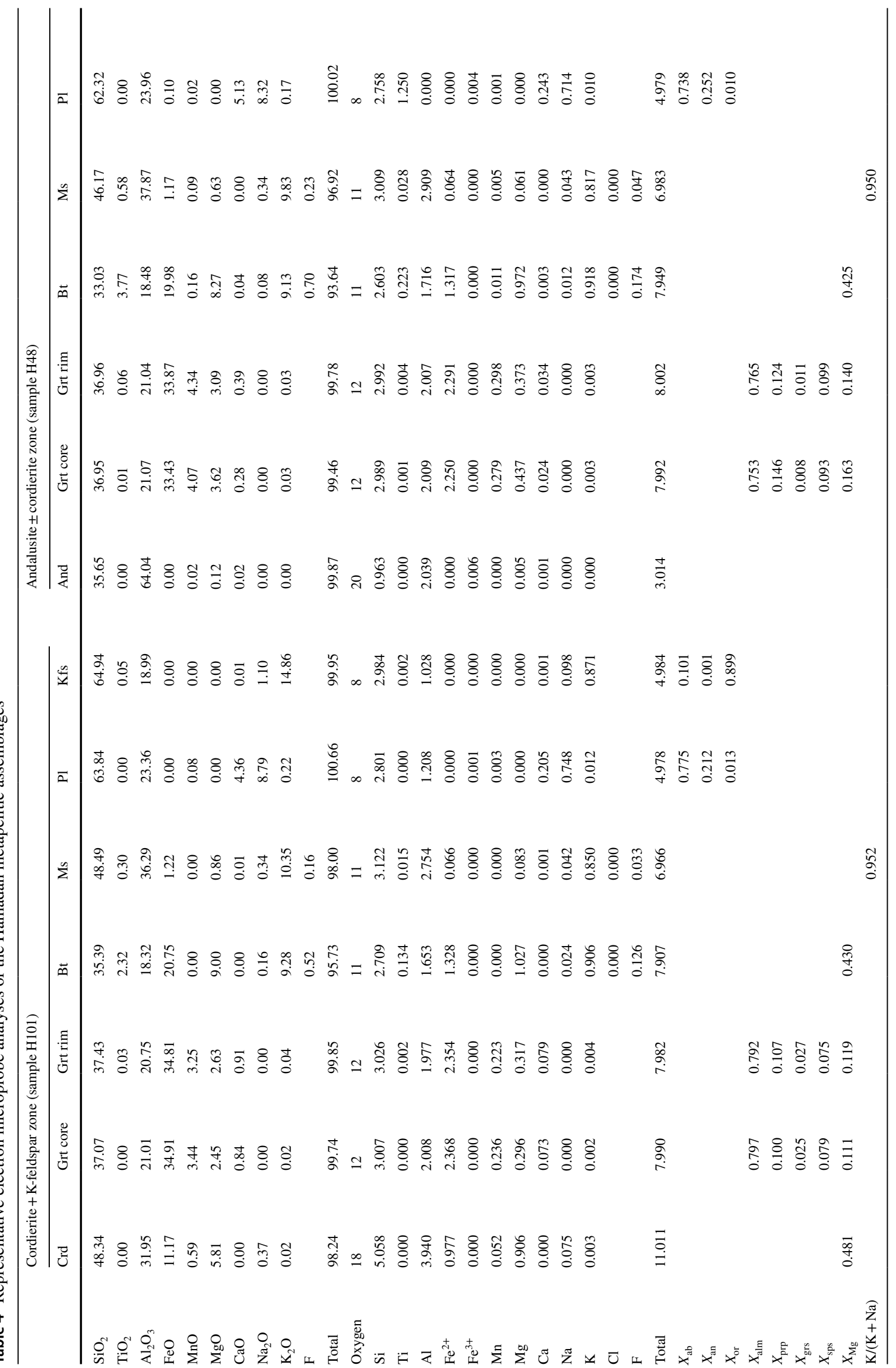




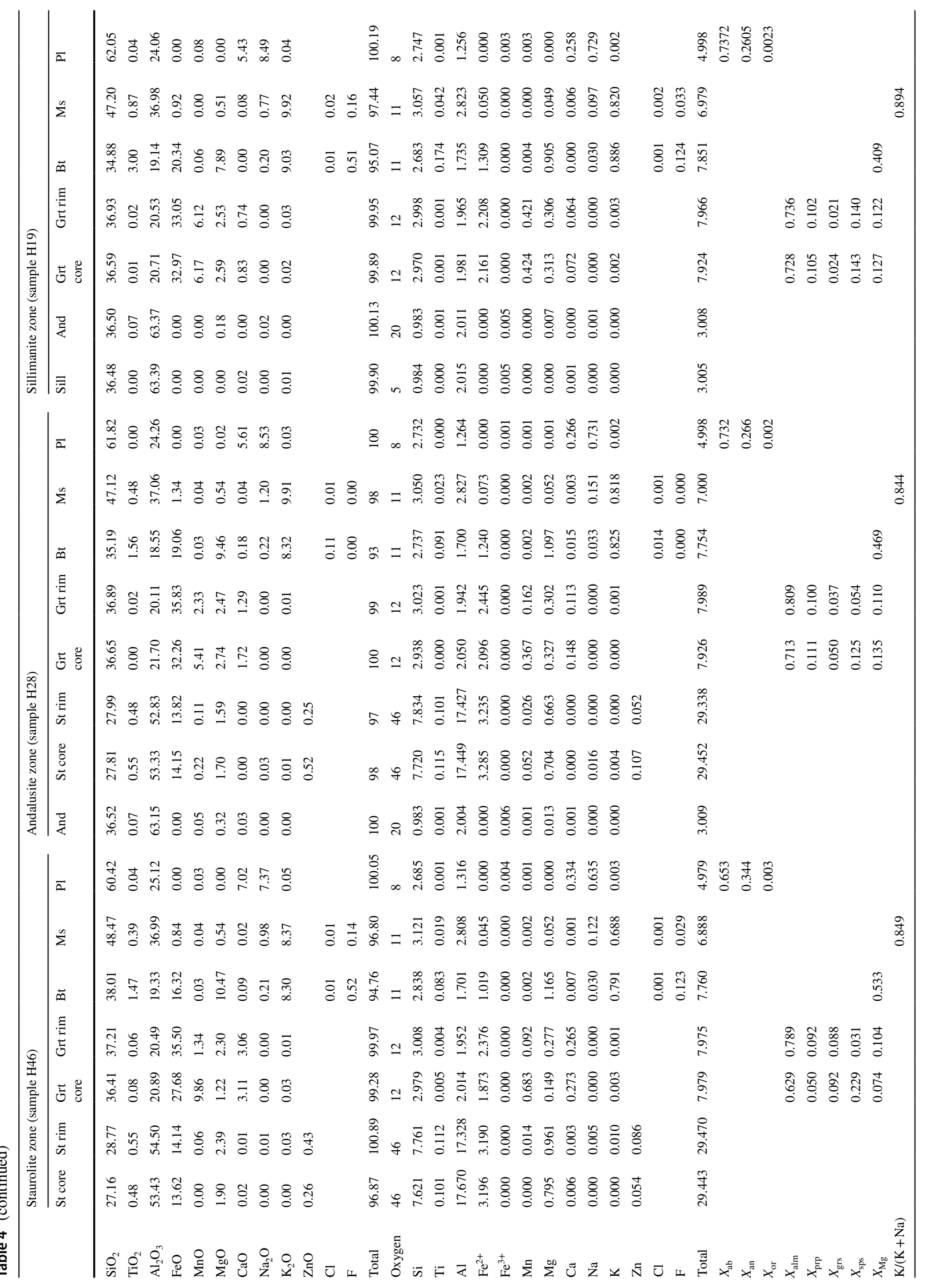



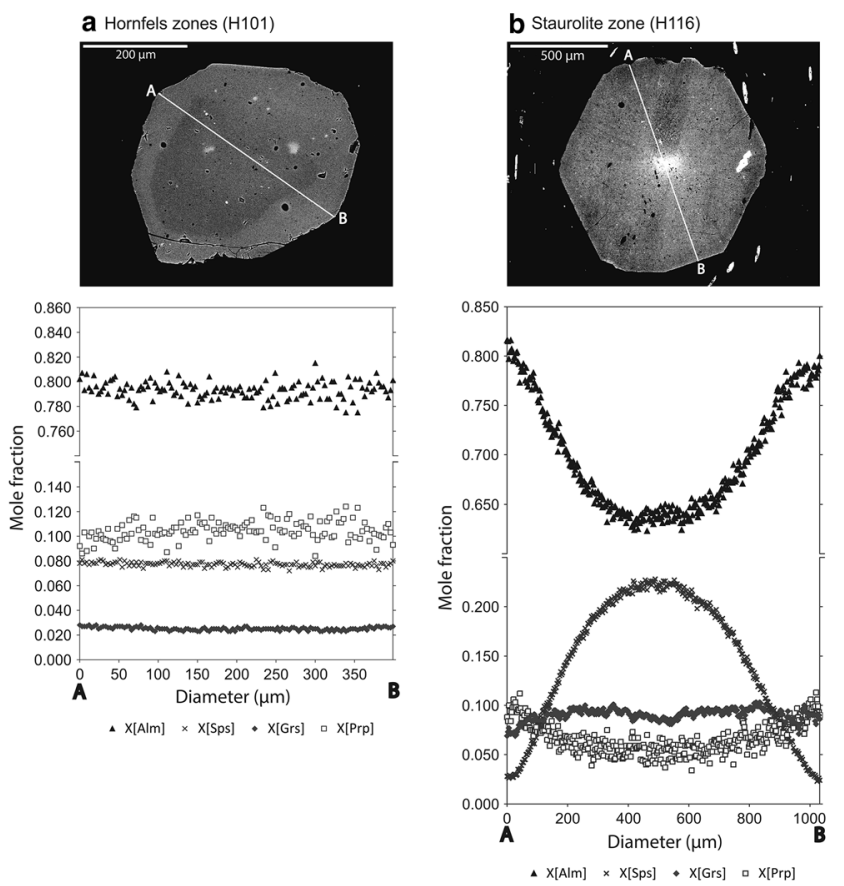

Fig. 5 a-d Compositional profiles across the largest garnet porphyroblasts observed in thin sections of the samples investigated in this study. Garnet zonation patterns are consistent with a prograde metamorphism. a $X_{\text {prp }}$ varies in higher values of mole fraction than $X_{\text {sps }}$

point of Pattison (1992). Activity models used in all calculations are those used in Tinkham and Ghent (2005) with the following exceptions: (1) margarite was not considered as a component in white mica, and (2) the ternary feldspar model of Holland and Powell (1998), using a molecular mixing model and asymmetric formalism, was used instead of separate plagioclase and pure orthoclase or sanidine. Excess $\mathrm{H}_{2} \mathrm{O}$ was assumed, and a melt phase was not considered in the modelling because only subsolidus processes are discussed. Although graphite is observed in samples, the assumption of a pure $\mathrm{H}_{2} \mathrm{O}$ fluid phase does not result in large discrepancies in the position of phase boundaries (Connolly and Cesare 1993; Pattison et al. 2002; Pattison 2006) and the presence of graphite probably resulted in a mixed C-O-H fluid (Connolly and Cesare 1993) during metamorphism.

Calculations were performed with samples containing representative mineral assemblages and bulk rock compositions of the defined five zones (Table 5). The initial constraints on the peak $P-T$ conditions recorded by each sample are imposed by the highlighted field within the relevant assemblage stability diagram, which contains the observed peak mineral assemblage identified in thin sections (Figs. 8, 9). Subsequently, two isobaric prograde paths are displayed that pass through the mineral-assemblage sequences from hornfels and schistose areas and cross the reaction boundaries on the equilibrium phase diagram, where minerals
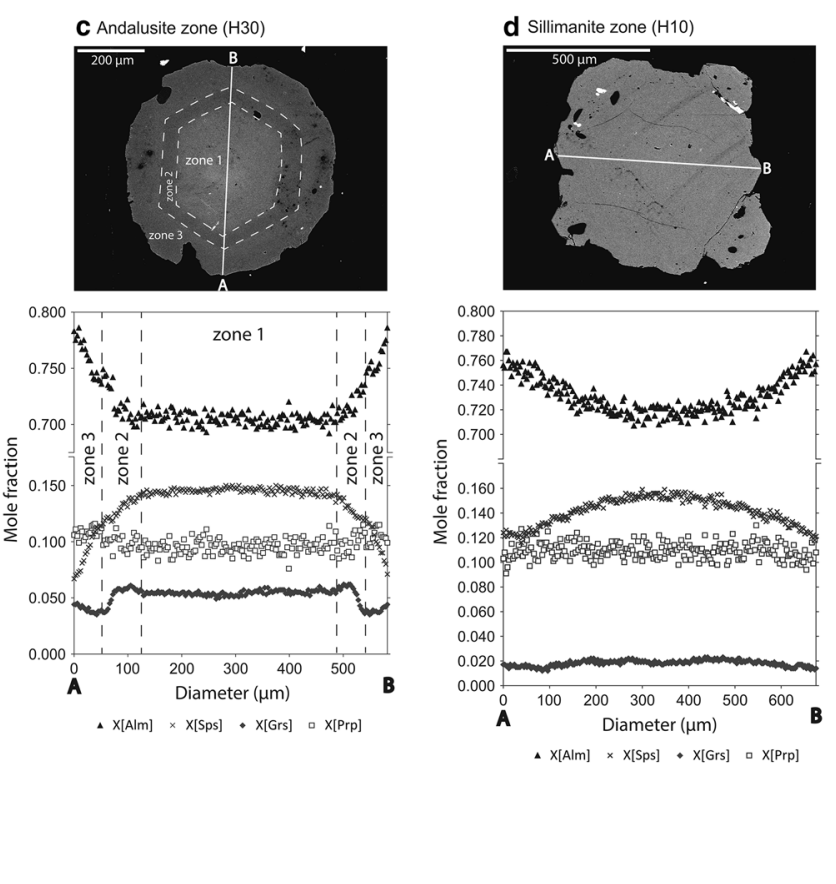

and $X_{\text {grs }}$ in the flat compositional zoning of garnet. $\mathbf{b}-\mathbf{d}$ The increase of $X_{\mathrm{alm}}$ and concomitant decrease of $X_{\mathrm{sps}}$ at the transition from core to rim compositions. $X_{\mathrm{grs}}$ and $X_{\mathrm{prp}}$ feature gentle compositional trends

are expected to be either found or lost from the mineral assemblage.

Figure 8 shows calculated assemblage stability diagrams for two metapelitic samples from the andalusite \pm cordierite and the cordierite $+\mathrm{K}$-feldspar zones. Sample H101 from the cordierite $+\mathrm{K}$-feldspar zone was taken exactly at the contact (Fig. 2a). The observed mineral assemblage $\mathrm{Crd}+\mathrm{Grt}+\mathrm{Bt}+\mathrm{Kfs}+\mathrm{Pl}+\mathrm{Qtz}+\mathrm{Ilm}$ defines a $P-T$ field in the calculations diagram of $570-670{ }^{\circ} \mathrm{C}$ and $<4 \mathrm{kbar}$. (Fig. 8b). Sample H48 from the andalusite + cordierite zone is located $\sim 5 \mathrm{~km}$ southeast of the contact (Fig. 2a) and comprises the stable mineral assemblage $\mathrm{And}+\mathrm{Grt}+\mathrm{Bt}+\mathrm{Ms}+\mathrm{Qtz}+\mathrm{Pl}+\mathrm{Ilm}$. The calculated phase stability field corresponds to lower pressure amphibolite facies with $T=550-630{ }^{\circ} \mathrm{C}$ and $P=2.8-3.8 \mathrm{kbar}$ (Fig. 8a). Texturally, the garnet inclusion in cordierite belongs to an early stage of metamorphism (M1) in the hornfels zones. A temperature increase towards the intrusion is clearly seen in these two samples, consistent with the higher average temperature in the cordierite $+\mathrm{K}$-feldspar zone derived from conventional geothermobarometry.

Mineral isograds in hornfelsic rocks can, therefore, be mapped around the intrusion and range from an outermost occurrence of And-in up to Crd + Kfs-in and And-out close to the aureole contact. Pattison and Tracy (1991) subdivided prograde sequences of the most common metapelitic 

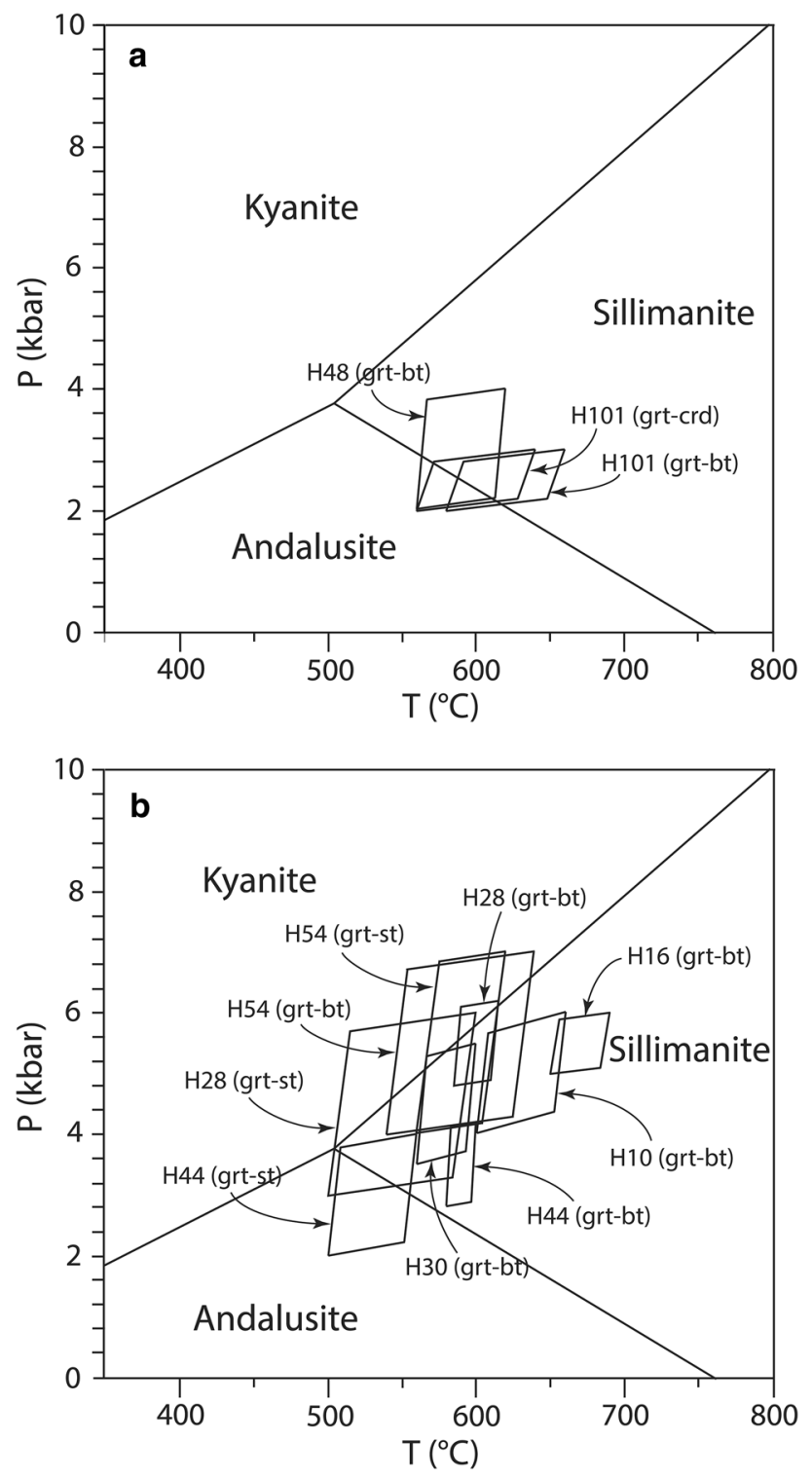

Fig. 6 Intersections of selected thermometers and barometers of representative samples obtained from conventional thermobarometry: a Hornfels zones; sample H101 is from the cordierite + K-feldspar zone, and sample $\mathrm{H} 48$ is from the andalusite \pm cordierite zone. b Schistose zones; samples H44 and H54 are from the staurolite zone, samples $\mathrm{H} 28$ and $\mathrm{H} 30$ are from the andalusite zone and samples $\mathrm{H} 10$ and $\mathrm{H} 16$ are from the sillimanite zone. A small systematic $P$ increase from the contact outwards is observed, but a constant pressure may be possible in the light of the uncertainties in the determination of peak pressures

assemblages into several facies series. The hornfels isobaric path comply with the facies series $1 / 2$ a bathograds that intersect the reactions 1, 2, 3 and 4 (Table 6; Fig. 10).

Sample H44 belongs to the staurolite zone and is located about $6 \mathrm{~km}$ east of the contact, just in the central part of the zone (Fig. 2a). The mineral assemblage $\mathrm{St}+\mathrm{Grt}+\mathrm{Bt}+\mathrm{M}$ $\mathrm{s}+\mathrm{Qtz}+\mathrm{Pl}+\mathrm{Ilm}$ is seen within a stability field extending from 560 to $640{ }^{\circ} \mathrm{C}$ and 3.5 to 7.5 kbar in Fig. 9a. Sample $\mathrm{H} 30$ east of the contact was chosen from the andalusite zone (Fig. 2a). The calculated equilibrium assemblage diagram shows a $P-T$ range of $540-640{ }^{\circ} \mathrm{C}$ and $2.5-4.0 \mathrm{kbar}$ for the observed mineral assemblage And $+\mathrm{Grt}+\mathrm{Bt}+$ $\mathrm{Ms}+\mathrm{Qtz}+\mathrm{Pl}+\mathrm{Ilm}$ (Fig. 9b). Staurolite is considered as a metastable phase. Several common reactions, such as $\mathrm{St} \rightarrow \mathrm{Grt}+\mathrm{Bt}+\mathrm{ALS}$, or $\mathrm{St}+\mathrm{Chl} \rightarrow \mathrm{ALS}+\mathrm{Bt}$, involve staurolite as reactant and produce an aluminosilicate (ALS) polymorph. Pattison and Spear (2018) noted that the width of zones of coexisting staurolite and andalusite in Buchantype sequences is much wider than predicted by equilibrium phase diagrams, which they attributed to disequilibrium processes related to sluggish dissolution of staurolite and the lack of a thermodynamic driving force for the conversion of staurolite to andalusite. Although the two samples from the staurolite (H30) and andalusite (H44) zones have different mineral assemblages, calculated equilibrium temperatures are similar. In sample $\mathrm{H} 44$ the assemblage is stable over a wider $P$ range and we conclude that low $P$ values, similar to H30, are likely. Sample H10 from the sillimanite zone has the largest distance to the contact (Fig. 2a). The mineral assemblage $\mathrm{Sil}+\mathrm{Grt}+\mathrm{Bt}+\mathrm{Ms}+\mathrm{Qtz}+\mathrm{Pl}+\mathrm{Ilm}$ is stable over a wide $P-T$ range of $540-770{ }^{\circ} \mathrm{C}$ and $3-8.5 \mathrm{kbar}$ (Fig. 9c). Since andalusite is present in the sample, we argue that the presence of sillimanite cannot significantly exceed the And-Sil reaction limiting the pressure to $<4$ kbar. The resulting $T$ is about $600-650{ }^{\circ} \mathrm{C}$.

Observed spacing of staurolite, andalusite and sillimanite isograds in the schistose part persuade us to propose an isobaric $P-T$ path at a pressure less than 1.0 kbar higher than the hornfels bathograd. The schistose isobaric path intersects reactions 5, 6 and 7 which conform with the facies series 2b/3 bathograd of Pattison and Tracy (1991) (Table 6; Fig. 10). The onset of the Sil-in and St-out isograd might, however, place this isobaric path to higher pressure through the intersection of the following reaction:

$\mathrm{Ms}+\mathrm{St}+\mathrm{Qtz}=\mathrm{Sil}+\mathrm{Bt}+\mathrm{H}_{2} \mathrm{O}$

At pressures of 3-4 kbar, the St-out isograd appears at temperatures between 550 and $585^{\circ} \mathrm{C}$ (Fig. 10).

\section{Geochronological results}

\section{U-Pb monazite data}

Monazites were analysed in four metapelitic samples (see Fig. 2a, c), one from the hornfels units (sample H101 from the crd +K-fsp zone) and three from the schistose units (sample H54 from the st zone, sample H31 from the And zone and sample H11 from the Sil zone). The monazites 
Fig. 7 Calculated by PET (Dachs 2004), the variation of temperatures of zones with distance from the contact is shown. The highest temperature belongs to the cordierite-bearing rocks close to the composite pluton- and sillimanite-bearing rocks far away from the contact

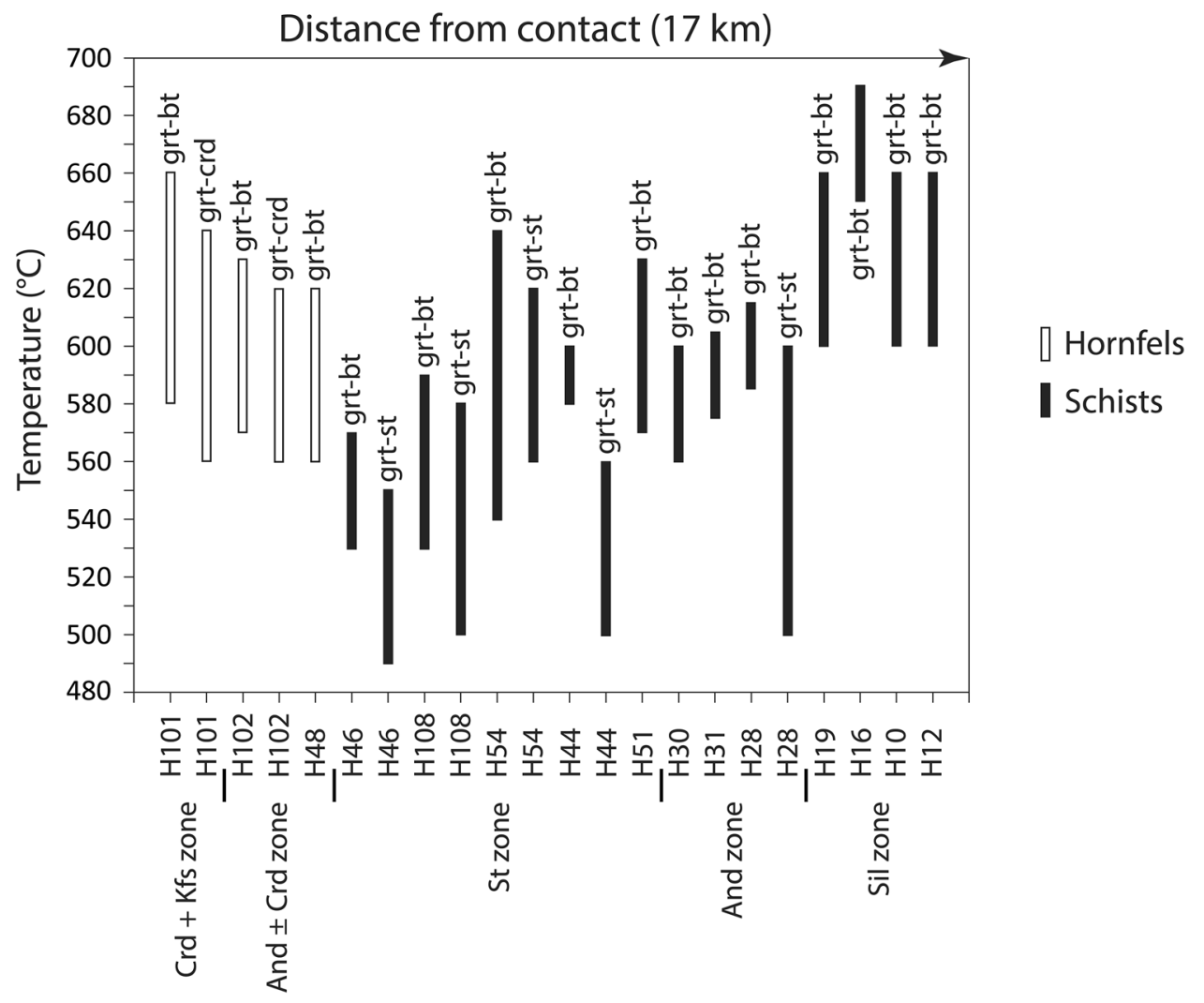

have maximum grain sizes of $30 \mu \mathrm{m}$ and elliptical to rounded shapes. In all cases, the monazite grains occur in the finegrained matrix, which is mainly composed of muscovite, and the grains are in textural equilibrium with the matrix. The small sizes of monazite allowed only 2 or 3 spot analyses in each grain. A large variation of monazite $\mathrm{ThO}_{2}{ }^{*}$ from 2 to $18 \mathrm{wt} \%$ in sample H101 marks an isochron at $168 \pm 11 \mathrm{Ma}$. The $\mathrm{ThO}_{2} *$ values show a broad cluster at around $6 \mathrm{wt} \%$ (Table S1; Fig. 11a). Some monazite analyses with $\mathrm{ThO}_{2} *<4 \mathrm{wt} \%$ plot considerably below the isochron. This population matches data from sample H54, where all monazites poorly define an errorchron of $47 \pm 51 \mathrm{Ma}$, mostly at low $\mathrm{ThO}_{2}{ }^{*}$. The samples $\mathrm{H} 11$ with $162 \pm 13 \mathrm{Ma}$ and $\mathrm{H} 31$ with $149 \pm 19$ Ma display a second small monazite populations at around 64-70 Ma along a poorly defined errorchron with $\mathrm{PbO}$ contents, which are just above the detection limit (Fig. 11a, b). The small population of Late Cretaceous to Paleocene monazites is also obvious in a diagram age vs. $\mathrm{Y}_{2} \mathrm{O}_{3}$ (Fig. 11b) and shows a chemically slightly different environment of monazite growth. The younger monazite ages of 64-70 Ma and 47 $\pm 51 \mathrm{Ma}$ are similar in age, within error, to our Ar-Ar mineral ages (see below).

There is a compositional trend from the main Middle Jurassic monazite population with 1-3 wt $\% \mathrm{Y}_{2} \mathrm{O}_{3}$ toward the younger population at around $1 \mathrm{wt} \% \mathrm{Y}_{2} \mathrm{O}_{3}$. Similar compositional trends from higher to lower $\mathrm{ThO}_{2}, \mathrm{UO}_{2}$ and $\mathrm{CaO}$ with decreasing ages are observed (not shown). As both samples from the hornfels units (H11 and H101) and sample H31 display similar isochrones at $R^{2}$ values between 0.85 and 0.93 , the monazite ages show a broad unimodal maximum at 160-180 Ma in the summarized histogram view (Fig. 11c). The minor Paleocene population appears also in the histogram and in the related averages. This age potentially implies a younger, second, Late Cretaceous to Paleogene thermal event.

\section{${ }^{40} \mathrm{Ar} /{ }^{39}$ Ar muscovite data}

White mica concentrates from eight samples were prepared to reveal potential age differences between hornfels and schistose zones (see Fig. 2a, c for sample locations). For measurements, 7-10 grains per sample were used. Analytical data are shown in Table S2. In the following, we describe the samples from various mineral assemblage zones in a transect from west to east. Nearly all concentrates yield minor extraneous argon in the first one to three steps and a plateau for major portions of the remaining steps of the experiment. An overview on significant properties of all investigated samples is given in Fig. 12.

Samples from the hornfels zones (H56 and H101) yield plateau ages of $80.21 \pm 0.44 \mathrm{Ma}$ and $76.61 \pm 0.42 \mathrm{Ma}$, respectively. The inverse isochron age of sample $\mathrm{H} 56$ is $81.8 \pm 3.7 \mathrm{Ma}$ with an initial ${ }^{40} \mathrm{Ar} /{ }^{36} \mathrm{Ar}$ ratio of $326 \pm 69$. The inverse isochron age of sample H101 is $73.4 \pm 2.6$ Ma with 


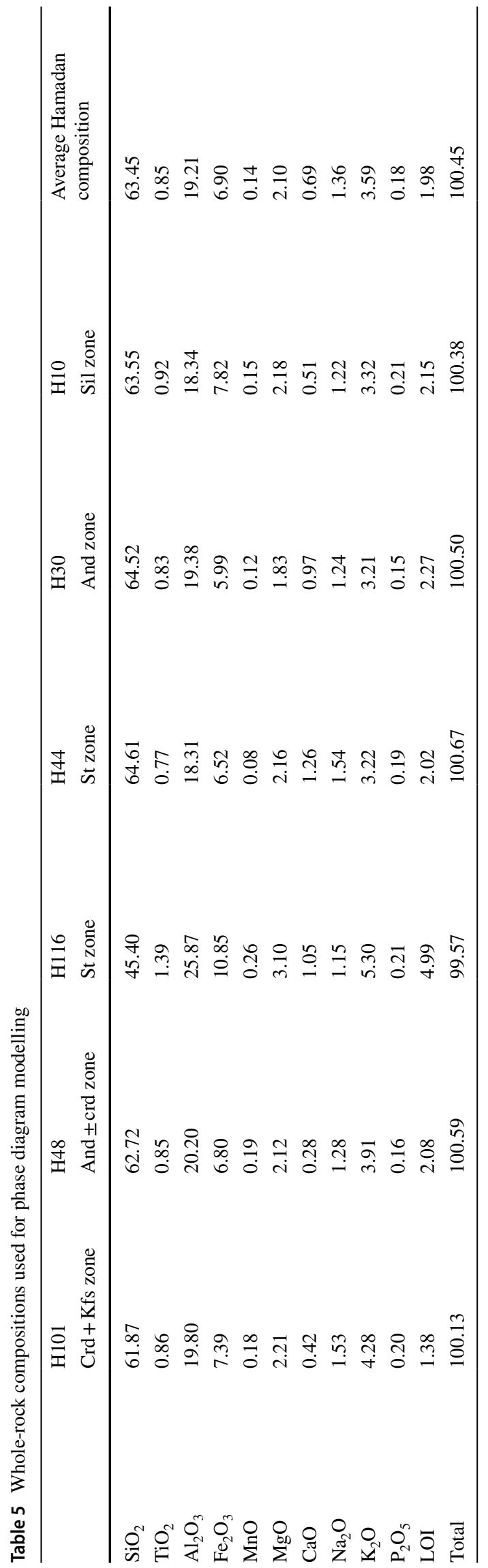

an initial ${ }^{40} \mathrm{Ar} /{ }^{36} \mathrm{Ar}$ ratio of $435 \pm 51$ indicating the presence of some excess argon significantly above the atmospheric ${ }^{40} \mathrm{Ar} /{ }^{36} \mathrm{Ar}$ ratio of 295.5 . We interpret, therefore, the plateau age of $76.61 \pm 0.42 \mathrm{Ma}$ as geologically significant, which excludes the first two steps with excess argon.

Both samples from the staurolite zone (H58 and H66) yield a weak staircase pattern with ages of $62.28 \pm 7.00 \mathrm{Ma}$ and $60.18 \pm 6.93 \mathrm{Ma}$ of the first steps indicating some Argon loss. Sample H58 yields a plateau age of $72.65 \pm 0.49 \mathrm{Ma}$, whereas for sample H66, the plateau age is $69.17 \pm 0.83 \mathrm{Ma}$ and the total gas age $71.33 \pm 0.41 \mathrm{Ma}$. The inverse isochron ages are $73.0 \pm 1.3 \mathrm{Ma}(\mathrm{H} 58)$ and $69.15 \pm 0.97$ (H66) with initial ${ }^{40} \mathrm{Ar} /{ }^{36} \mathrm{Ar}$ ratios of $231 \pm 25$ and $265 \pm 37$, respectively. We consider the plateau ages of $72.65 \pm 0.49 \mathrm{Ma}$ (sample H58) and $69.17 \pm 0.83 \mathrm{Ma}$ (H66) as geologically significant, whereas the first-step ages indicate a later overprint and Ar loss.

Two samples from the andalusite zone (H32 and H68) give plateau ages of $73.50 \pm 0.38 \mathrm{Ma}$ and $73.66 \pm 0.45 \mathrm{Ma}$. The isochron ages are $72.32 \pm 0.94 \mathrm{Ma}(\mathrm{H} 32)$ and $70.6 \pm 3.0 \mathrm{Ma}(\mathrm{H} 68)$ with initial ${ }^{40} \mathrm{Ar} /{ }^{36} \mathrm{Ar}$ ratios of $322 \pm 45$ and $522 \pm 240$, respectively, the later potentially including some extraneous argon. Finally, samples H11 and H67 are from the sillimanite zone. Sample H1 1 exhibits a plateau age of $70.59 \pm 0.24 \mathrm{Ma}, \mathrm{H} 67$ a plateau age of $70.84 \pm 0.26 \mathrm{Ma}$. The inverse isochron ages are $68.6 \pm 3.8 \mathrm{Ma}(\mathrm{H} 11)$ and $69.7 \pm 9.0 \mathrm{Ma}(\mathrm{H} 67)$ with initial ${ }^{40} \mathrm{Ar} /{ }^{36} \mathrm{Ar}$ ratios of $412 \pm 90$ and $436 \pm 190$, respectively.

In most cases, the inverse isochron ages (including all steps) are close to the plateau ages. Thus, we suggest that the ages from all four investigated zones are geologically significant and represent the ages of cooling through the argon retention in white mica, which is at $425 \pm 25^{\circ} \mathrm{C}$ in regional metamorphic areas (Harrison et al. 2009). In summary, the two plateau ages of the hornfels zones are significantly older (80.21 and 76.61 Ma), whereas the ages of all schistose zones vary between 70.59 and $73.66 \mathrm{Ma}$ within a relatively narrow age range.

\section{${ }^{40} \mathrm{Ar} /{ }^{39} \mathrm{Ar}$ amphibole data}

We selected four amphibolite samples of the staurolite zone (H61, H114, H119, H120), which are not affected by retrogression, for ${ }^{40} \mathrm{Ar} /{ }^{39} \mathrm{Ar}$ dating. Optically uniform amphibole grains free from macroscopically visible inclusions were selected for dating. Ca. 10 grains were then finally used for the experiment and because of the relatively low potassium content, ca. 7-9 steps were measured until fusion. All four samples show U-shaped argon release patterns (Fig. 13) and exhibit excess argon in the first 2 to 3 steps, followed by ca. three relatively large steps with low apparent ages and then an increase in ${ }^{40} \mathrm{Ar}$ content in the final steps. The ${ }^{37} \mathrm{Ar}_{\mathrm{Ca}}{ }^{39} \mathrm{Ar}_{\mathrm{K}}$ ratio is between 5.8 to and 12 meaning 

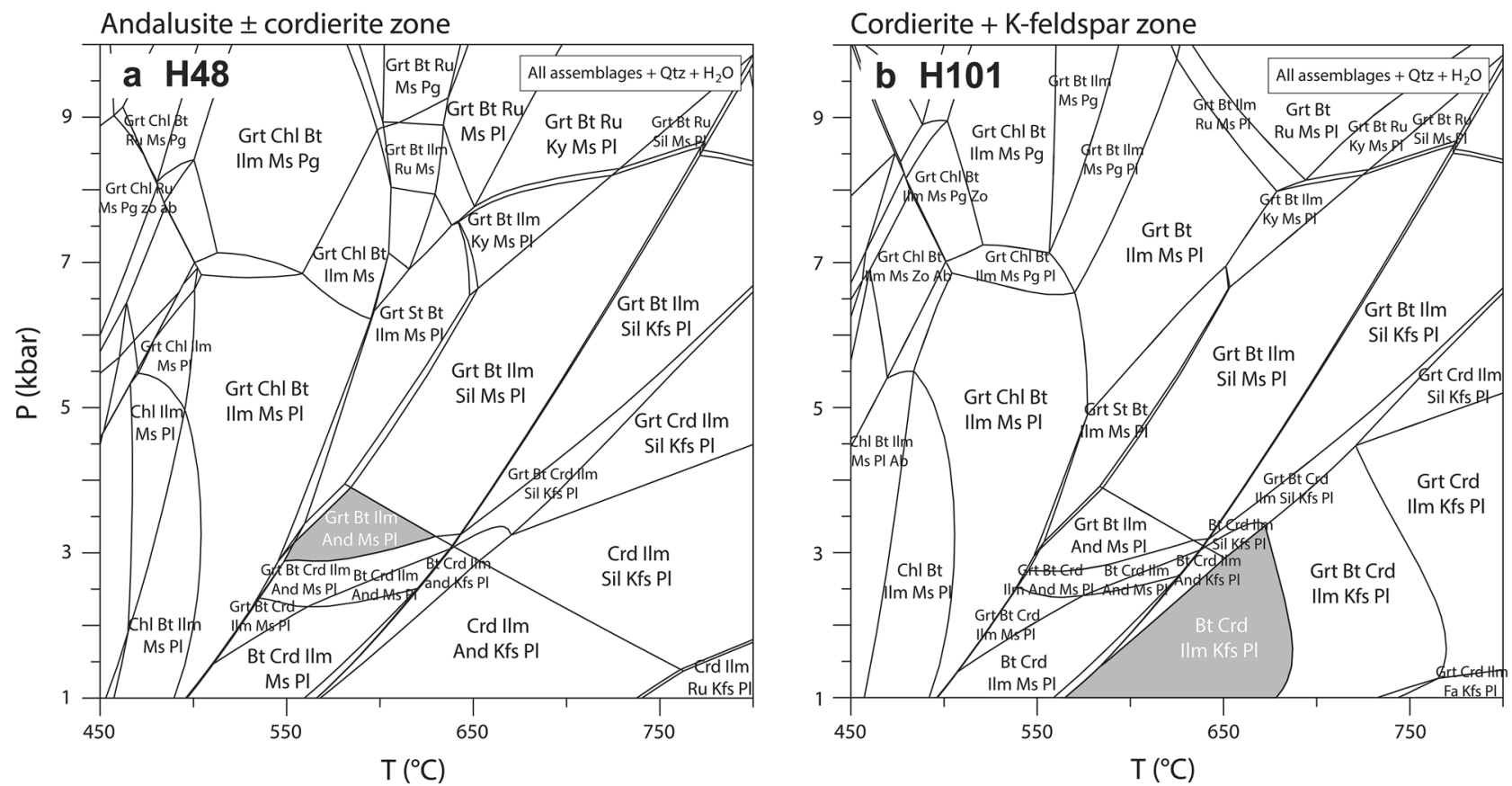

Fig. 8 Equilibrium assemblage diagrams for the bulk compositions of two hornfels samples. The field for the appropriate peak assemblage identified in each sample is highlighted

relatively low potassium contents in all four amphibole concentrates. These central three steps yield similar ages between minimum $62.6 \pm 2.4 \mathrm{Ma}$ (sample H120) and maximum 72.9 $\pm 1.1 \mathrm{Ma}$ (sample H61). The total gas ages (corresponding approx. $\mathrm{K}-$ Ar ages) range between $79.0 \pm 1.1 \mathrm{Ma}$ and $93.7 \pm 1.4 \mathrm{Ma}$, reflect extraneous argon incorporated in the sample and are geologically meaningless. Sample H61 also shows the highest $\mathrm{K}$ content with a ${ }^{37} \mathrm{Ar}_{\mathrm{Ca}}{ }^{39} \mathrm{Ar}_{\mathrm{K}}$ ratio between 5.8 and 6.7 and yields a weighted mean age of $73.9 \pm 1.1 \mathrm{Ma}$. We consider this age as geologically significant and to either reflect the maximum age of the third stage of metamorphism M3 or the age of cooling through ca. $550{ }^{\circ} \mathrm{C}$. The age is also very close to the age of white mica from nearby samples of the schistose units. The other three amphibole samples are in full support of this Cretaceous age although the youngest age is slightly younger than white mica ages from other samples.

\section{Discussion}

The metamorphic framework of the Hamadan complex presented in this study constrains three stages, M1-M3, in metapelitic rocks which show a progressive change in mineral assemblages and mineral chemistry. Together with age dating results and the regional geological framework, the results argue for a reinterpretation of the geological and tectonic history of this specific part of the Sanandaj-Sirjan zone. We first discuss details of the metamorphic $P-T$ conditions, then the age dating results and finally we propose, based on our results, a new tectonic model for the Hamadan metamorphic complex.

\section{$P-T$ conditions of the three metamorphic stages}

Besides the overall stability field of inferred peak metamorphic assemblages, the $P-T$ conditions can further be constrained using the chemical composition of minerals.

The mineral assemblage related to M1 metamorphism is constrained exclusively by garnet grains enclosed in cordierite of M2. The prograde metamorphic evolution of M1 can only be vaguely constrained by feldspar and chlorite inclusions in garnet. The compositional zoning of M1 garnet in hornfels samples $\mathrm{H} 101$ is negligible and thus no $P-T$ variation from core to rim is envisaged. The measured composition is characterized by a high amount of $X_{\text {alm }}$ ranging from 0.78-0.81, $X_{\text {prp }}$ of $0.09-0.12$ and $X_{\text {sps }}=0.07-0.08$ and $X_{\mathrm{grs}}=0.02-0.03$. Using the isopleths of the grossular and pyrope components, we constrain the $P-T$ conditions of $\mathrm{M} 1$ garnet growth to $\sim 575-725^{\circ} \mathrm{C}$ and $\sim 3-5.5 \mathrm{kbar}$. However, the chlorite inclusions in this garnet generation favour $P-T$ conditions closer to the lower range with $\sim 575{ }^{\circ} \mathrm{C}$ and $\sim 3-5$ kbar, just outside of the chlorite stability field (Fig. 14).

The results of conventional thermobarometry show a systematic increase in temperature toward the contact from 


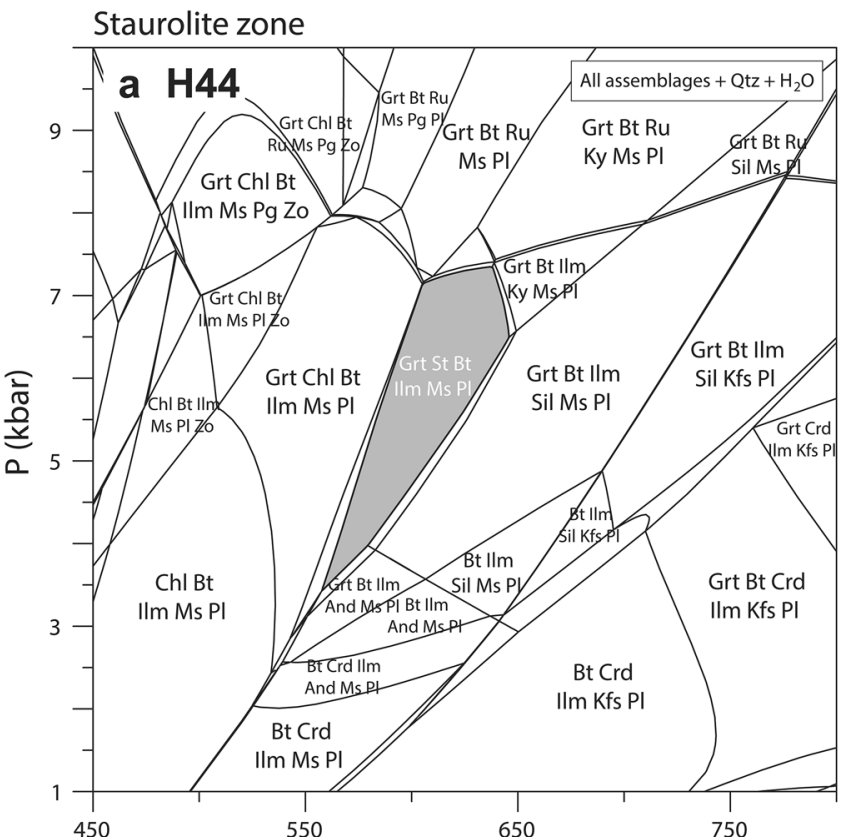

Sillimanite zone

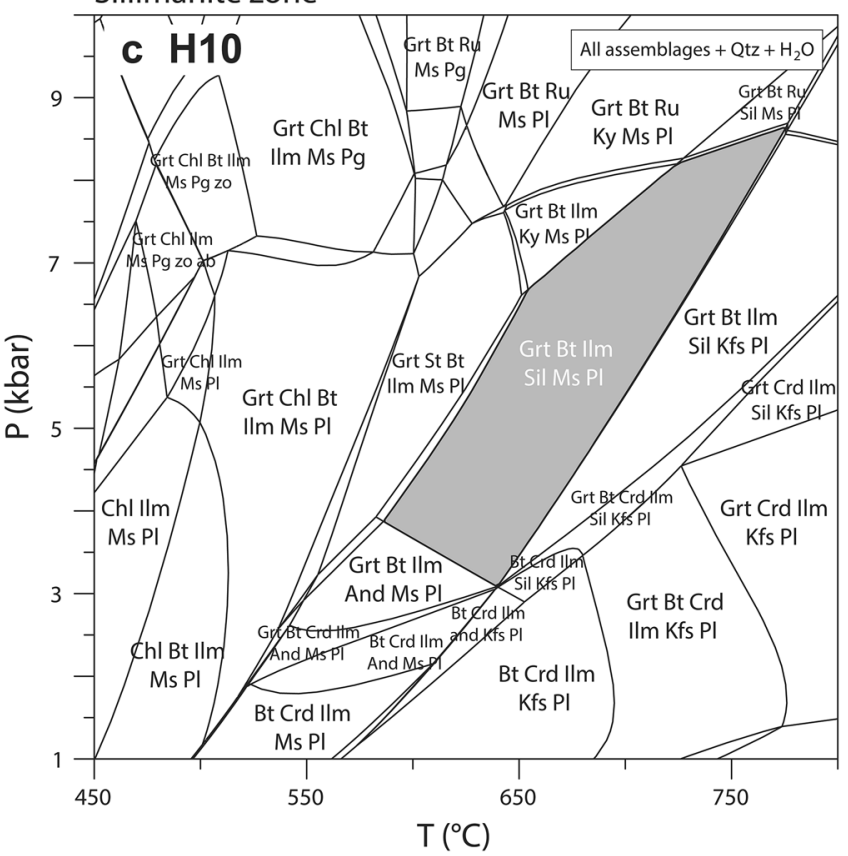

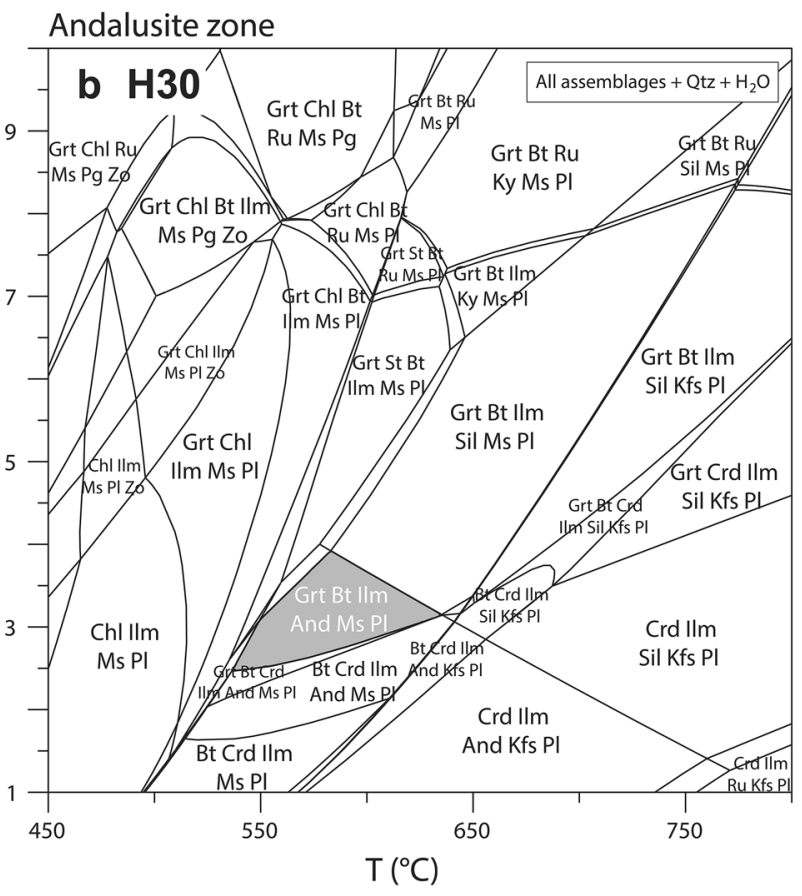

Fig. 9 Equilibrium assemblage diagrams for the bulk compositions of three schistose samples. The field for the appropriate peak assemblage identified in each sample is highlighted

andalusite-bearing rocks (zone 2) to cordierite-bearing rocks (zone 1) in the hornfels area (M2 metamorphism, Fig. 7). There is no systematic trend in temperatures across the schistose region (zones 3-5, M3 metamorphism) toward the contact. However, application of the GASP and GBMP barometers indicate slightly lower pressures for the hornfels zones (Fig. 6). The equilibrium assemblage diagram approach allowed us to further constrain the observed mineral assemblages to gradients in pressure and temperature within the Hamadan area. Although zones 1-2 and zones 3-5 display typical low pressure, high-temperature mineral assemblages, we were able to identify a systematic difference in pressure and thus propose two different prograde evolutions for hornfels and schistose rocks. Consequently, 
Table 6 Mineral reactions related to assemblages in the Hamadan metapelites

\begin{tabular}{llll}
\hline & $\begin{array}{l}\text { Reaction number in } \\
P-T \text { phase diagram }\end{array}$ & Reaction label & Simplified reaction in KFMASH \\
\hline Hornfels zones & 1 & And-in (from Chl) & $\mathrm{Ms}+\mathrm{Chl}+\mathrm{Qtz}=\mathrm{And}+\mathrm{Bt}+\mathrm{H}_{2} \mathrm{O}$ \\
& 2 & And to Crd (Chl-free) & $\mathrm{Bt}+\mathrm{And}+\mathrm{Qtz}+\mathrm{H}_{2} \mathrm{O}=\mathrm{Ms}+\mathrm{Crd}$ \\
& 3 & And $+\mathrm{Kfs}-\mathrm{in}$ & $\mathrm{Ms}+\mathrm{Qtz}=\mathrm{Kfs}+\mathrm{And}+\mathrm{H}_{2} \mathrm{O}$ \\
Schistose zones & 5 & And to Crd $+\mathrm{Kfs}-\mathrm{in}$ & $\mathrm{Bt}+\mathrm{And}+\mathrm{Qtz}=\mathrm{Crd}+\mathrm{Kfs}^{+} \mathrm{H}_{2} \mathrm{O}$ \\
& 6 & St-in (from Chl) & $\mathrm{Ms}+\mathrm{Chl}=\mathrm{St}+\mathrm{Bt}+\mathrm{Qtz}+\mathrm{H}_{2} \mathrm{O}$ \\
& 7 & St to And (Chl-free) & $\mathrm{Ms}+\mathrm{St}+\mathrm{Qtz}=\mathrm{And}+\mathrm{Bt}+\mathrm{H}_{2} \mathrm{O}$ \\
& Sil-in (from And) & And $=\mathrm{Sil}$ \\
\hline
\end{tabular}

Numbered reactions are shown in Fig. 10 and discussed in the text

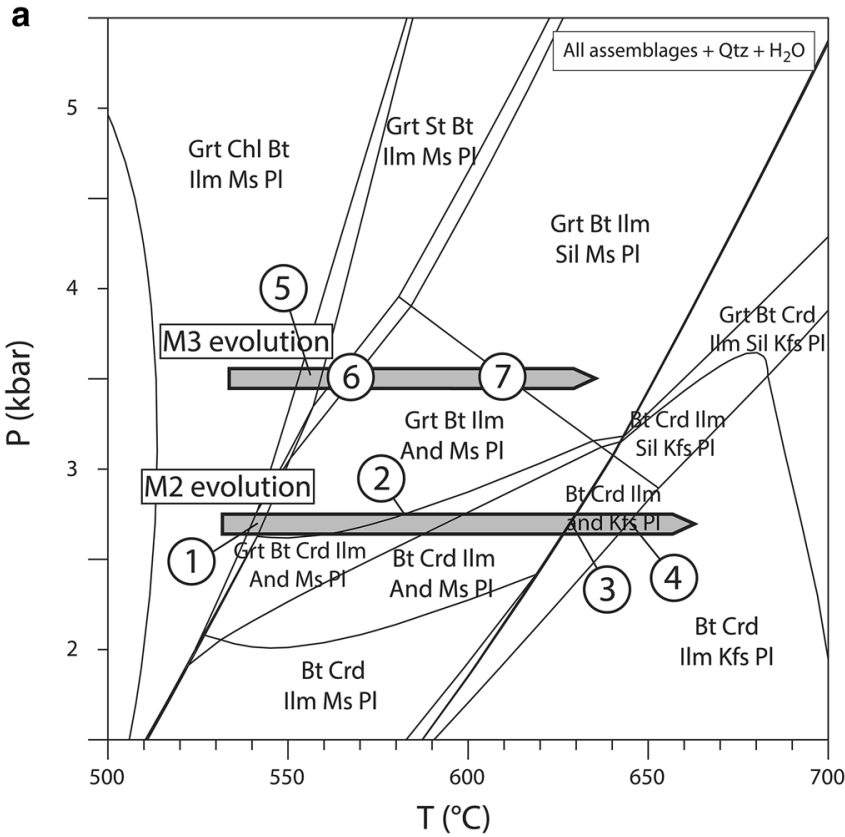

Fig. 10 a Equilibrium assemblage diagram for the average Hamadan metapelite composition in the MnNCKFMASHT system. b Calculated isopleths of $X_{\mathrm{grs}}$ and $\mathrm{Mg} \#(\mathrm{Mg} /(\mathrm{Mg}+\mathrm{Fe}))$ of garnet. The isobaric paths are located on (a) and (b) representing the prograde evo-

we argue that the successive appearance and disappearance of andalusite and cordierite, contact metamorphism (M2), is related to increasing temperature toward the Alvand composite pluton at isobaric conditions of $\sim 2.7 \mathrm{kbar}$ (Fig. 10). Due to the large areal extension and the absence of plutonic rocks in the foliated metamorphic rocks and irregular distribution of metamorphic field-gradients towards the Alvand composite pluton, contact metamorphism is excluded to be responsible for the low $\mathrm{P}$ mineral assemblages in zones 3-5. We propose a different, Buchan-style metamorphic event (M3) for the staurolite-andalusite-sillimanite sequence at slightly higher pressures of $3.5 \mathrm{kbar}$ (Fig. 10). The metamorphic overprint developed together with the deformation along the eastern side of the composite pluton. b

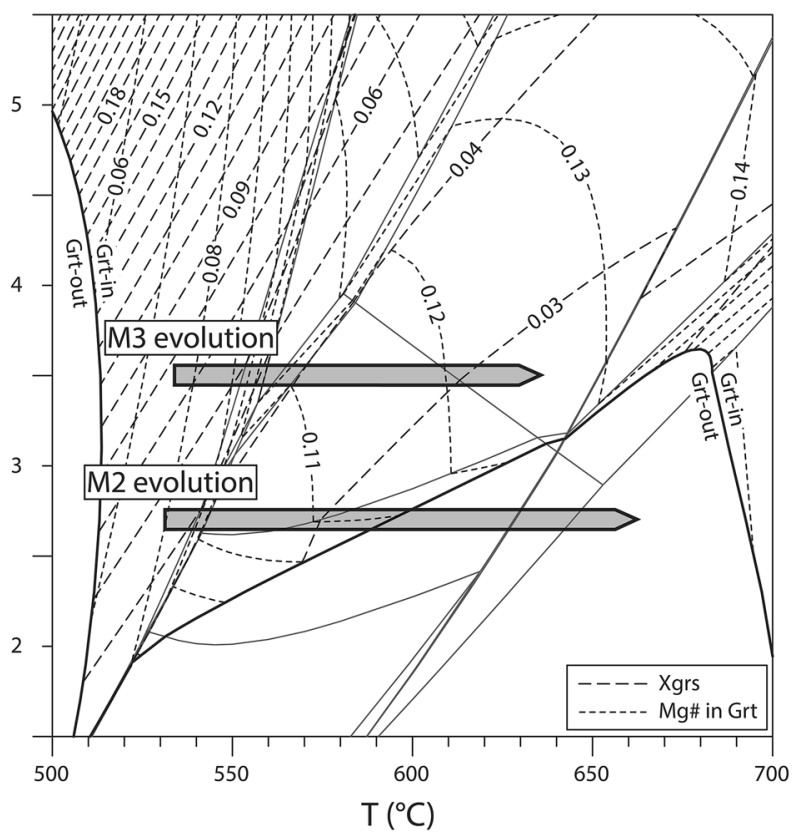

lution of M3 metamorphism and contact metamorphism in different pressure. The location of the isobaric paths implies the most common assemblages of minerals in each hornfels and schistose part. Numbered reactions are listed in Table 6

\section{Age of M2 and M3 metamorphism}

Although lithological and mineralogical features have been widely described, some controversies persist regarding the metamorphic age of the Hamadan complex. The Alvand composite pluton formed during Middle Jurassic times, as established by several U-Pb zircon ages. (Shahbazi et al. 2010; Mahmoudi et al. 2011; Sepahi et al. 2018) However, for the Hamadan metamorphic complex, both the $\mathrm{K}-\mathrm{Ar}$ muscovite and amphibole ages from the literature (Baharifar et al. 2004; Valizadeh and Cantagrel 1975) and the new white mica and amphibole ${ }^{40} \mathrm{Ar} /{ }^{39} \mathrm{Ar}$ ages from this study are much younger, Late Cretaceous, for both the hornfels and schistose zones. Consequently, crystallization of the plutons 

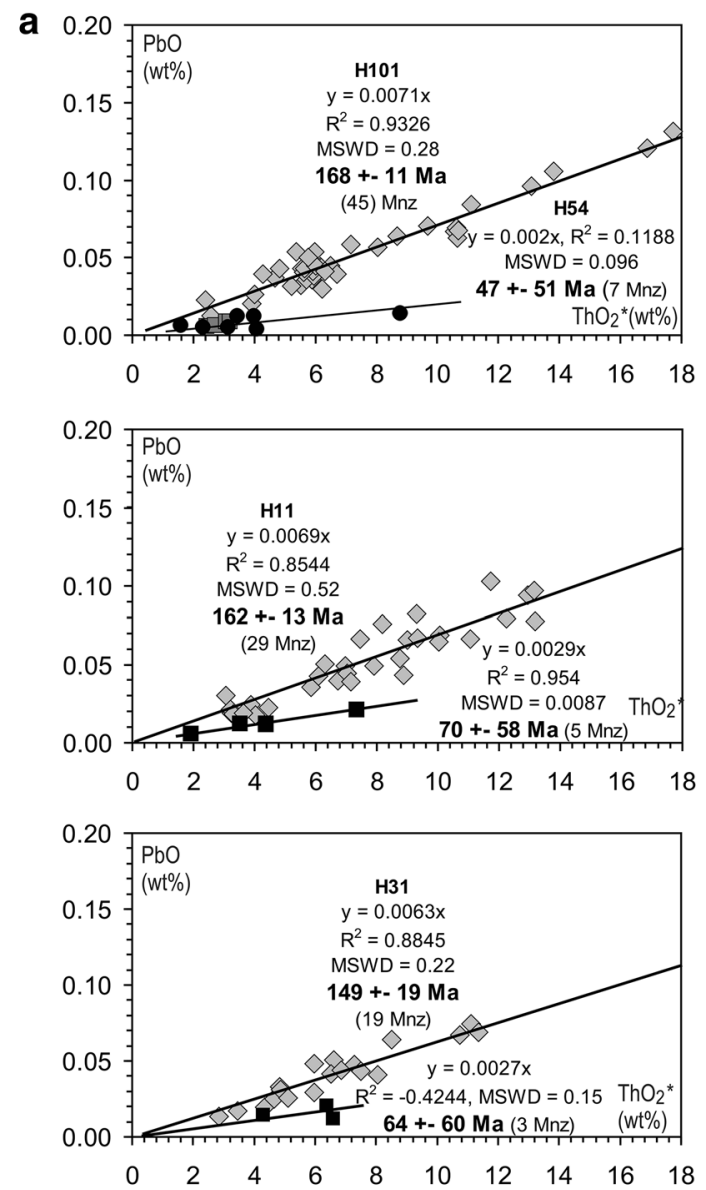

Fig. 11 a Th-U-Pb chemical model ages of monazite (Mnz). Total $\mathrm{ThO}_{2}{ }^{*}$ vs $\mathrm{PbO}$ (wt\%) isochron diagrams; $\mathrm{ThO}_{2}{ }^{*}$ is $\mathrm{ThO}_{2}+\mathrm{UO}_{2}$ equivalents expressed as $\mathrm{ThO}_{2}$, after Suzuki et al. (1994). General minimal error $2 \sigma$ on monazite $\mathrm{PbO}$ analysis is shown in a bar. Regression lines with the coefficient of determination $R^{2}$ are forced through

pre-dates cooling after the latest peak metamorphic conditions by about 90 million years.

Valizadeh and Cantagrel (1975) reported biotite and muscovite ages ranging from 68 to $104 \mathrm{Ma}(\mathrm{Rb}-\mathrm{Sr})$ and 68-89 Ma (K-Ar) from the Alvand granitoid complex. Given the more recent $\mathrm{U}-\mathrm{Pb}$ zircon and monazite ages of 153-172 Ma for various lithologies (gabbros, granitoids, pegmatites) of the Alvand pluton (Table 1), this implies that the Alvand pluton was also affected by a Late Cretaceous metamorphic event, which is much younger than the Jurassic age of intrusion. This is consistent with the observation that the schistose Aliabad-e Damaq granite gneiss with an age of $164.2 \pm 5.4 \mathrm{Ma}$ belongs to the large Alvand composite pluton and is affected by formation of a metamorphic foliation postdating the intrusion.

The monazite age of $168 \pm 11$ Ma from the cordierite + K-feldspar zone (sample H101) taken at the contact is within error the same as the age of granite intrusion. The monazite age of $149 \pm 19$ Ma from the andalusite
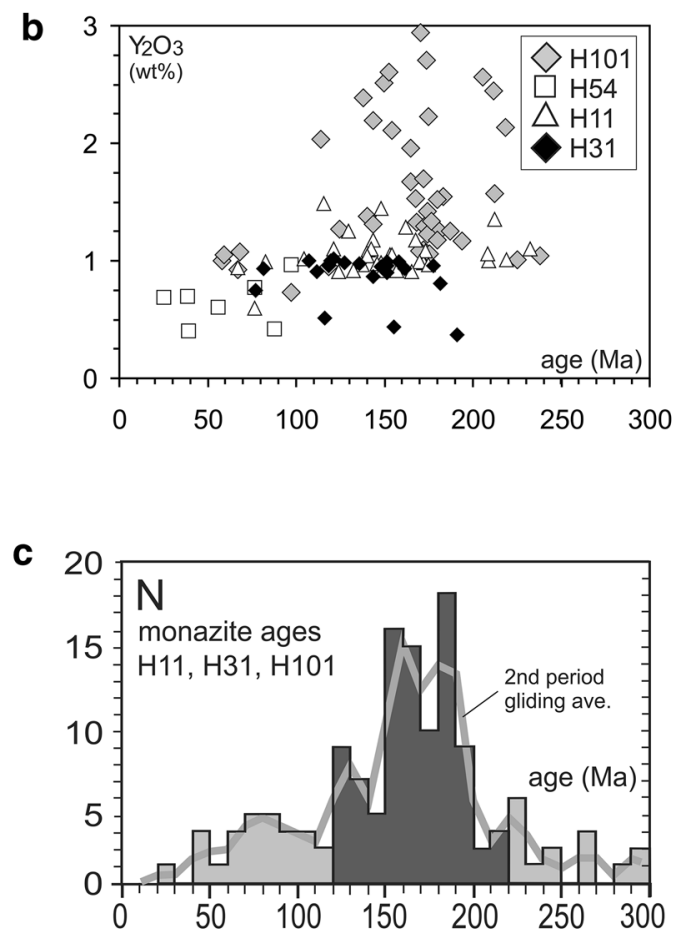

zero as proposed by Suzuki et al. (1994) and Montel et al. (1996). Weighted average ages (Ma) with MSWD and minimal error of $2 \sigma$ are calculated from single analyses according to Ludwig (2001). b $\mathrm{Y}_{2} \mathrm{O}_{3}$ content vs. age. c Age histogram from the few monazite samples dated by microprobe

zone (sample H31) overlaps within error with these ages. Experimental work suggests that closure temperatures for $\mathrm{Pb}$ in monazite are typically in the range between 900 and $1100{ }^{\circ} \mathrm{C}$, depending on cooling rate and grain size (Cherniak et al. 2004). Hence, volume diffusion of $\mathrm{Pb}$ in monazite is very slow and inefficient (McFarlane and Harrison 2006) and unlikely to cause grain-scale resetting under the metamorphic conditions experienced by the Hamadan metamorphic complex. Therefore, these monazite ages are interpreted to represent the age of the metamorphic event M2 as they are similar, within error, to the $\mathrm{U}-\mathrm{Pb}$ zircon intrusion ages of the pluton.

The ${ }^{40} \mathrm{Ar} /{ }^{39} \mathrm{Ar}$ white mica ages of the hornfels are between 80.2 and $76.6 \mathrm{Ma}$, whereas the white mica ages of all metasedimentary rocks from the schistose zones are within a narrow range between 73.7 and $69.2 \mathrm{Ma}$ (Campanian, Late Cretaceous). Considering the fading of the schistosity towards the Alvand composite pluton and our new ${ }^{40} \mathrm{Ar} /{ }^{39} \mathrm{Ar}$ white mica ages between 80 and $70 \mathrm{Ma}$ and 

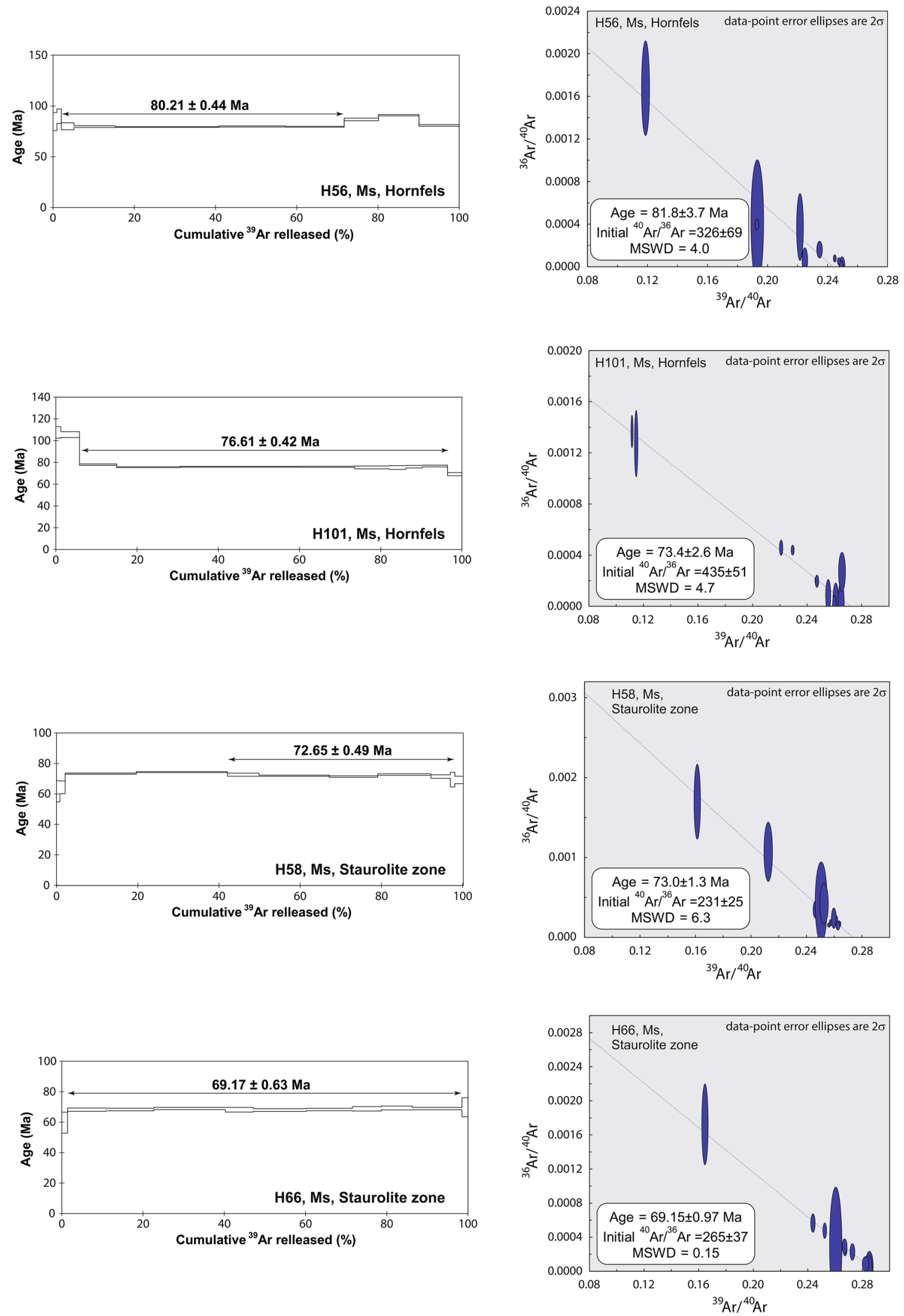

Fig. 12. ${ }^{40} \mathrm{Ar} /{ }^{39} \mathrm{Ar}$ release patterns of white mica from the Hamadan metamorphic complex 

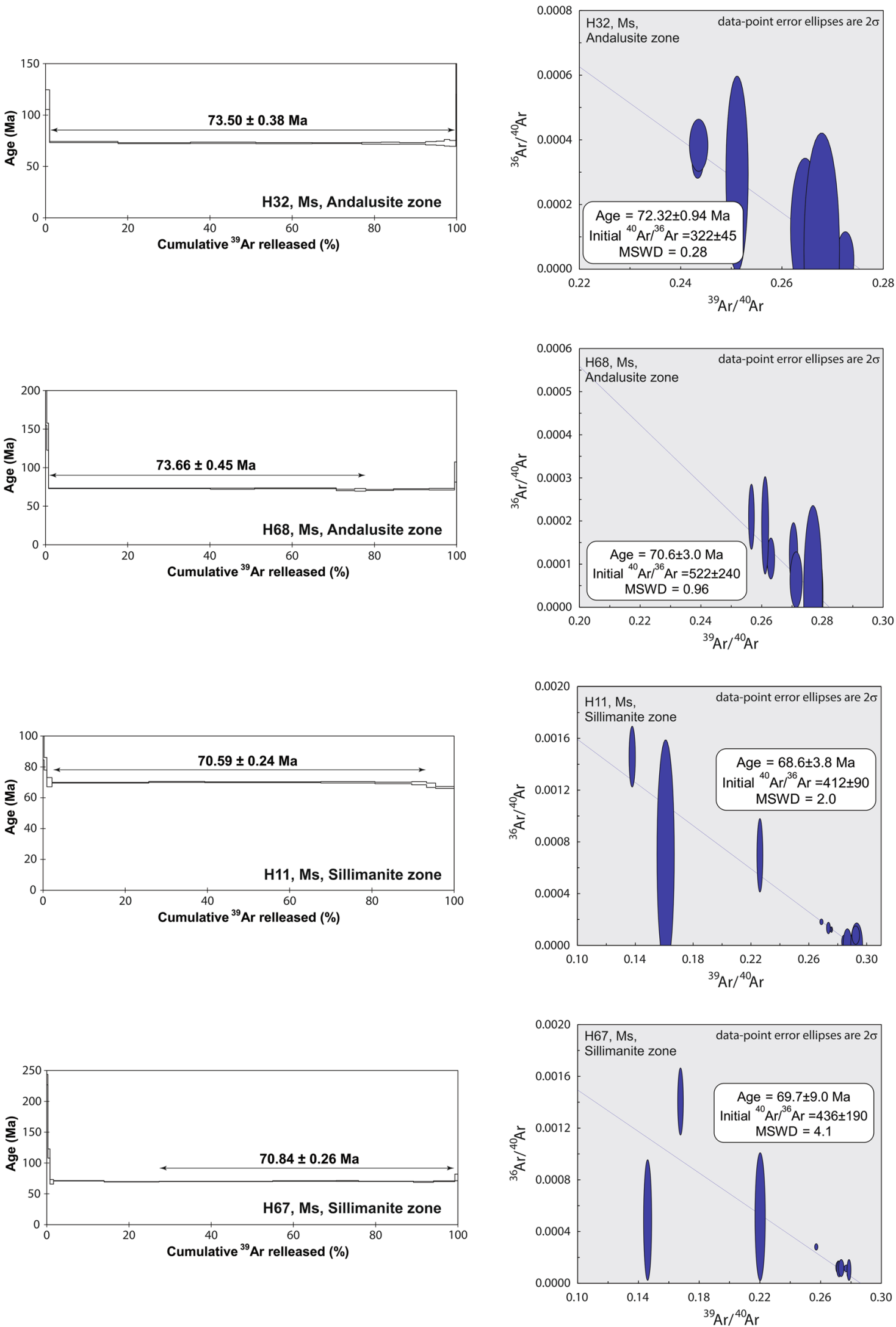

Fig. 12. (continued) 

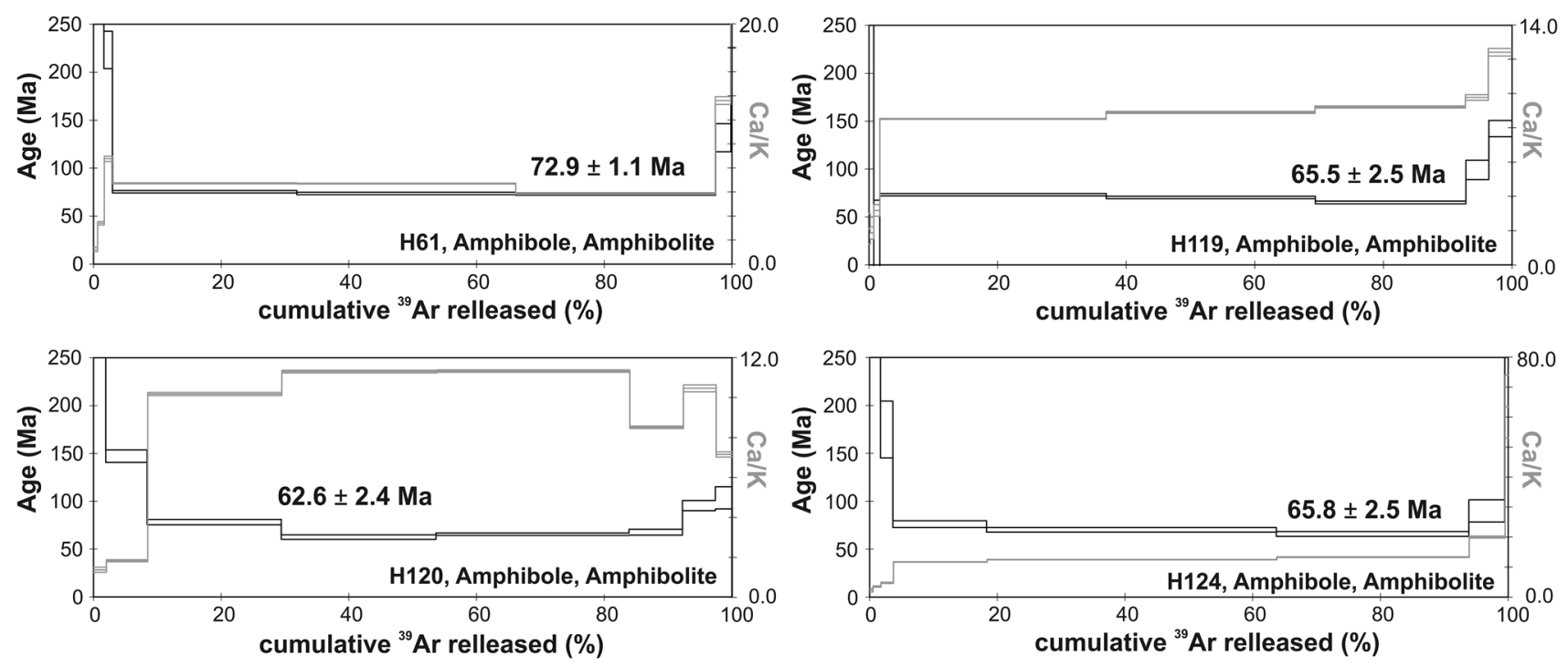

Fig. 13. ${ }^{40} \mathrm{Ar} /{ }^{39} \mathrm{Ar}$ release patterns of amphibole from the Hamadan metamorphic complex
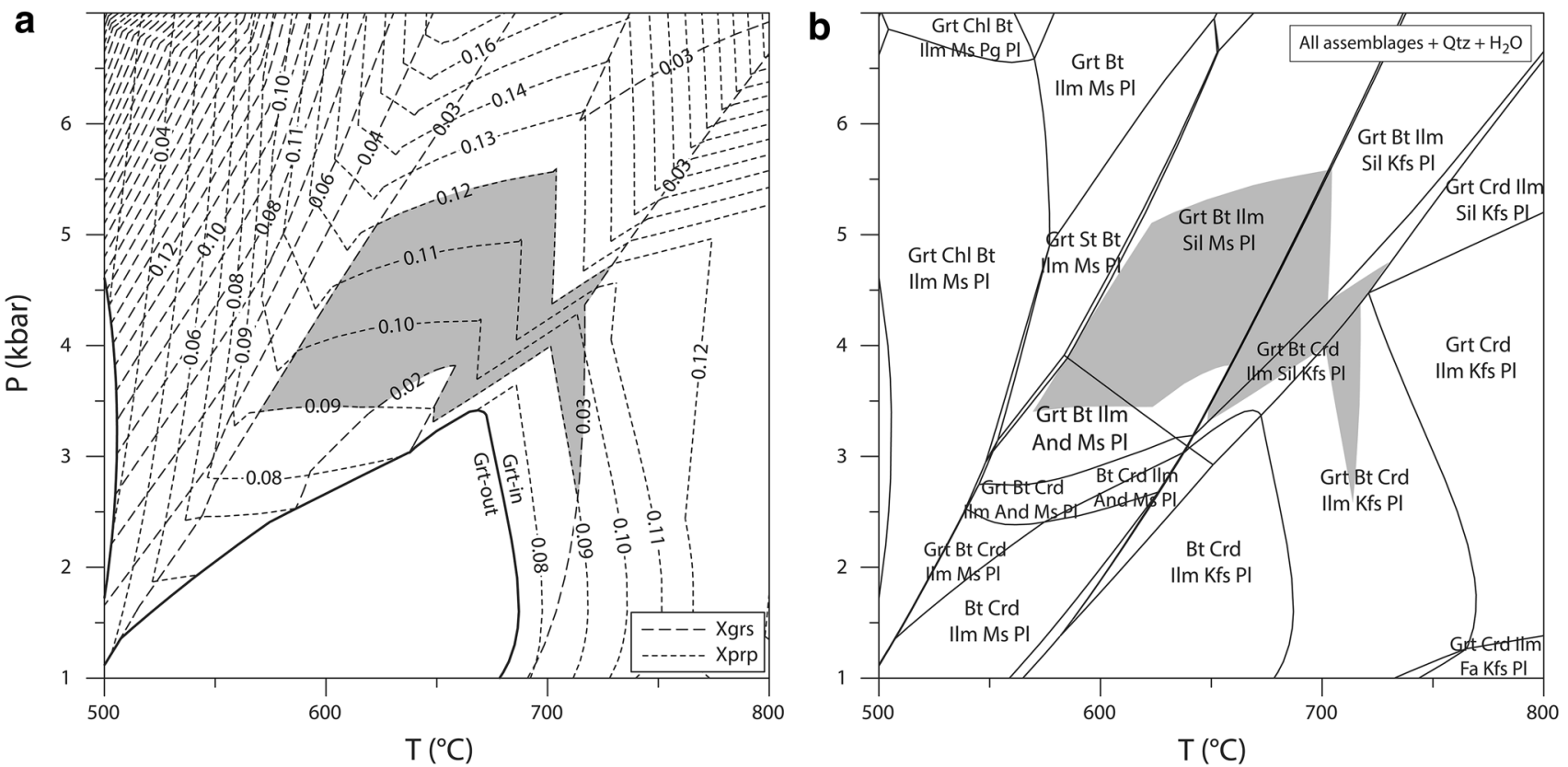

Fig. 14 a Estimated field of M1 garnet stability as constrained by compositional isopleths of $X_{\mathrm{grs}}$ and $X_{\mathrm{prp}}$ corresponding to the garnet composition in Fig. 5a. b $P-T$ phase diagram showing overlap of this domain with stability field of mineral assemblages

amphibole ages between 73 and $63 \mathrm{Ma}$, we argue that the M3 metamorphic event is much younger and occurred in the Late Cretaceous. Although imprecise due to the large uncertainty, the monazite population of $64-70 \mathrm{Ma}$ and $47 \pm 51 \mathrm{Ma}$ is similar in age to the Late Cretaceous amphibole and white mica ${ }^{40} \mathrm{Ar} /{ }^{39} \mathrm{Ar}$ ages. These ages are similar to few $\mathrm{K}-\mathrm{Ar}$ white mica ages reported by Baharifar et al. (2004), which range between $68.7 \pm 1.6 \mathrm{Ma}$ and $76.7 \pm 1.9 \mathrm{Ma}$. Baharifar et al. (2004) also reported $\mathrm{K}-\mathrm{Ar}$ amphibole ages of
$114.6 \pm 4.3 \mathrm{Ma}$ and $82.3 \pm 2.4 \mathrm{Ma}$ as well as some $\mathrm{K}-\mathrm{Ar}$ biotite ages ranging from $67.4 \pm 1.7$ to $59.4 \pm 1.5 \mathrm{Ma}$. The oldest $\mathrm{K}-\mathrm{Ar}$ amphibole age of $115 \pm 4.3 \mathrm{Ma}$ (Baharifar et al. 2004) is likely to have been affected by extraneous argon, the presence of which was demonstrated by our argon release patterns and is thus considered geologically meaningless. The Late Cretaceous to Paleocene ages of all four amphibole concentrates from the amphibolites (Fig. 13) argue that $\mathrm{M} 3$ exceeded $550{ }^{\circ} \mathrm{C}$ according to experimental calibration 
initially proposed by Harrison (1981). These new geochronological data establish that a distinct metamorphic event that reached amphibolite-facies metamorphic conditions affected the Hamadan metamorphic complex in the Late Cretaceous. Because of the similar, overlapping ${ }^{40} \mathrm{Ar} /{ }^{39} \mathrm{Ar}$ amphibole and white mica ages, the age of pervasive deformation forming white mica during ductile deformation is considered to have been just after peak conditions of M3. In addition, this Late Cretaceous thermal event affected not only the Hamadan complex but also the seemingly undeformed Alvand composite pluton. Interestingly, a similar monazite age of $61 \pm 8$ Ma was reported for the Soursat complex in the northwestern Sanandaj-Sirjan zone (Jamshidi Badr et al. 2010) implying a larger area affected by this latest Cretaceous to earliest Paleogene metamorphism.

These relationships argue for the following interpretation: The latest regional metamorphism (M3) in the Hamadan complex is younger than metamorphism in the upper unit east of the Tafrijan-Mangavi-Kandelan fault. Unfortunately, there are no geochronological ages constraining the age of metamorphism in the upper unit, but it is significantly of lower grade. Agard et al. (2005) demonstrated, based on Raman spectroscopy, a temperature difference of about $100{ }^{\circ} \mathrm{C}$ from $387^{\circ} \mathrm{C}$ in the upper unit vs. $487^{\circ} \mathrm{C}$ in the lower unit across the Tafrijan-Mangavi-Kandelan fault. These authors found ca. NNW-SSE trending stretching lineation with top to the SSE motion, overprinted by ESE-directed extensional shear bands. We, therefore, speculate that the Tafrijan-Mangavi-Kandelan fault represents a ductile lowangle normal fault, which was active during Late Cretaceous and the cause for the exhumation and cooling of the Hamadan metamorphic complex. Agard et al. (2005) already noted the special significance of this fault representing a break in metamorphic conditions. However, future studies should focus on the age of metamorphism in the upper unit and reveal more details on the kinematic evolution of the Tafrijan-Mangavi-Kandelan fault.

\section{Cooling history of the Hamadan metamorphic complex}

Regional cooling after the latest regional metamorphic event (M3) can be inferred from the Ar retention temperature of metamorphic amphibole $\left(550 \pm 25^{\circ} \mathrm{C}\right)$ and muscovite $\left(425 \pm 25{ }^{\circ} \mathrm{C}\right)$ which occurred just after peak $P-T$ conditions. In Fig. 15, we compile all thermochronological data from the region including our new $\mathrm{Ar}-\mathrm{Ar}$ ages and an apatite (U-Th)/He age (22.1 \pm 0.70 Ma: François et al. 2014). The cooling path since ca. 80-75 Ma, after the M3 metamorphic event, reached ca. $6{ }^{\circ} \mathrm{C} / \mathrm{Ma}$. The cooling through ca. $60^{\circ} \mathrm{C}$, the He retention temperature in apatite, occurred virtually contemporaneous with deposition of the Oligocene-Miocene succession at top (Fig. 2a, b). Final cooling through

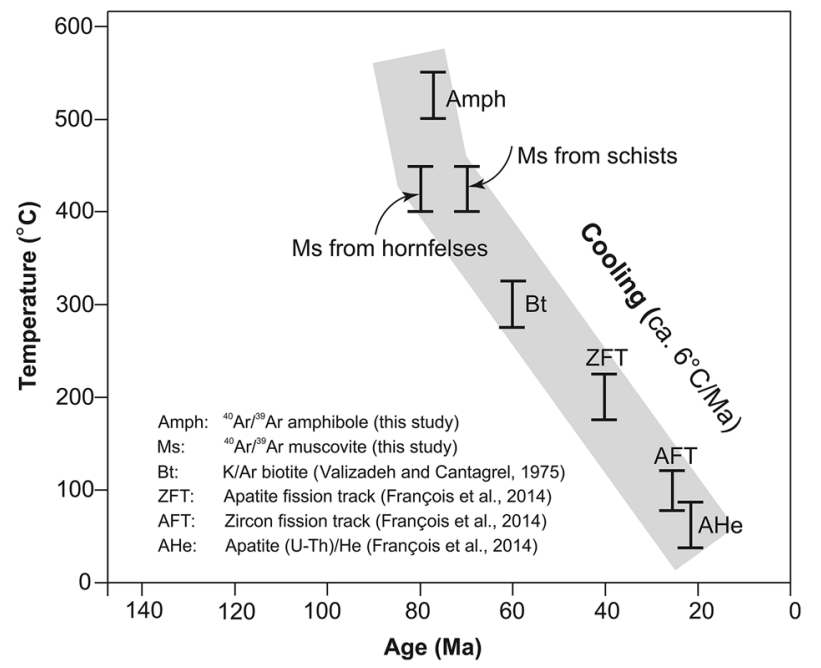

Fig. 15 Time-integrated cooling rates of the Hamadan metamorphic complex, combining the results of ${ }^{40} \mathrm{Ar} /{ }^{39} \mathrm{Ar}$ age dating of investigated rock samples and previous geochronological data from the Hamadan complex

the helium retention temperature in apatite is related to final exhumation and erosional denudation after final closure of the Neotethyan suture (Agard et al. 2011).

\section{Tectonic implications}

The new data on $P-T$ conditions and ages allow to propose a new geodynamic model (Fig. 16), which incorporates data from the literature (e.g., Agard et al. 2011; Chiu et al. 2013; Shakerardakani et al. 2015; Hassanzadeh and Wernicke 2016) and also the M3 metamorphic event defined in this study. The short-lived Middle Jurassic pulse of intrusions including the Alvand composite pluton, which was emplaced between $171.1 \pm 1.2$ and $153.3 \pm 2.7 \mathrm{Ma}$, is the result of Neotethyan subduction (e.g., Shahbazi et al. 2010; Mahmoudi et al. 2011; Sepahi et al. 2018; Fig. 16a). This is the stage of contact metamorphism (M2). Production of calc-alkaline magmas ceased during Late Jurassic and only few Early Cretaceous magmatic rocks formed. We argue that the formation of the schistosity in the Hamadan Phyllite directly pertains to M3 and is the result of ductile deformation, which is related to the initial exhumation of the Hamadan metamorphic complex. This interpretation explains why the schistose zonation fades westwards to the Alvand composite pluton. The most straightforward interpretation is to relate foliation formation to the Tafrijan-Mangavi-Kandelan fault and slow exhumation of the Hamadan metamorphic complex could be explained by Late Cretaceous cooling and exhumation. This would need a major Late Cretaceous event of extension within the Sanandaj-Sirjan zone potentially triggered by southwestward retreat of the subduction zone during rollback and steepening of the Neotethyan Ocean (Fig. 16b). 


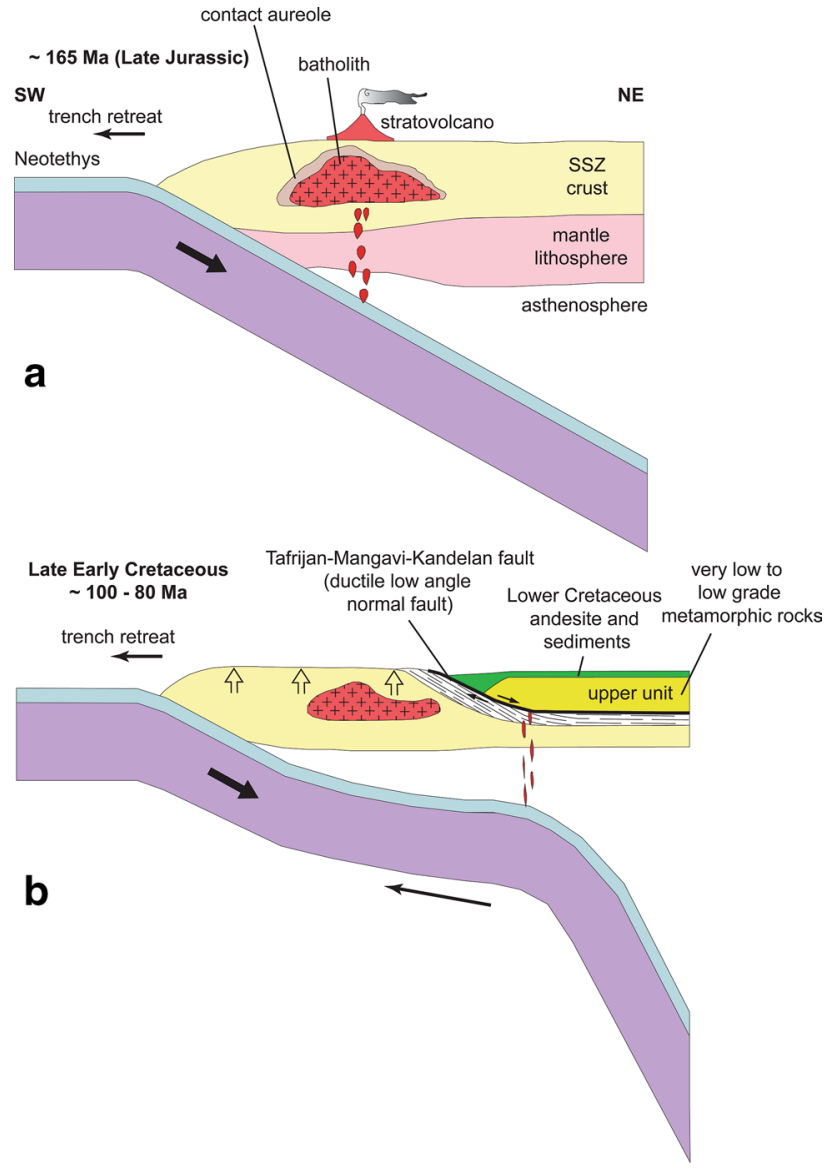

Fig. 16 Tectonic model for the geodynamic framework. a MiddleLate Jurassic subduction of the Neotethyan oceanic lithosphere and formation of the Alvand composite pluton. b Late Cretaceous exhumation and cooling of the Hamadan metamorphic complex triggered by extension due to retreat of the subduction zone and steepening of the Neotethyan oceanic lithosphere. SSZ Sanandaj-Sirjan zone

Such an event is well known and resulted in the opening of back-arc basins, e.g., Late Cretaceous Nain-Baft back-arc basin (e.g., Agard et al. 2011; Hassanzadeh and Wernicke 2016 and references therein). Our new data argue that the main stage of regional metamorphism, M3, in this sector of the Sanandaj-Sirjan zone is of Late Cretaceous age and is related with ductile low-angle normal faulting and extension during opening of mentioned back-arc basins.

Acknowledgements Open access funding provided by University of Graz. Special thanks to Karl Ettinger for microprobe assistance. Bernardo Cesare is thanked for review and comments on an initial version of this manuscript. Philippe Agard is greatly appreciated for his detailed and constructive review that served to greatly improve the manuscript. We are also grateful to Andrea Zanchi and two anonymous journal reviewers for their comments and suggestions. Editorial work by Ingo Braun led to substantial improvement of this work. Behzad Monfaredi acknowledges support through a scholarship from the Afro-Asiatisches Institut Graz for his PhD thesis at the Karl-FranzensUniversity Graz.
Open Access This article is licensed under a Creative Commons Attribution 4.0 International License, which permits use, sharing, adaptation, distribution and reproduction in any medium or format, as long as you give appropriate credit to the original author(s) and the source, provide a link to the Creative Commons licence, and indicate if changes were made. The images or other third party material in this article are included in the article's Creative Commons licence, unless indicated otherwise in a credit line to the material. If material is not included in the article's Creative Commons licence and your intended use is not permitted by statutory regulation or exceeds the permitted use, you will need to obtain permission directly from the copyright holder. To view a copy of this licence, visit http://creativecommons.org/licenses/by/4.0/.

\section{Appendix: Analytical techniques}

\section{Whole rock-element measurements}

Whole-rock analyses were performed by using a Bruker Pioneer S4 X-ray fluorescence spectrometer at the Institute of Earth Sciences, Karl-Franzens-University Graz. One gram of sample powder and seven grams of $\mathrm{Li}_{2} \mathrm{~B}_{4} \mathrm{O}_{7}$ flux were fused to a glass bead for XRF measurement. About 80 international reference rock powders were used for standardization, the reproducibility is better than $1 \%$ for major elements and better than 5\% for trace elements. Detection limits are for most elements $20 \mathrm{ppm}$. The whole rock chemistry of samples is shown in Table 5 .

\section{Mineral composition}

Mineral compositions were determined at the NAWI Graz Geocenter-Institute of Earth Sciences, Karl-Franzens-University Graz with a JEOL 6310 electron scanning microscope equipped with a LINK ISIS energy dispersive spectrometer (EDS) and a MICROSPEC wavelength dispersive system (WDS). The emission current is operated with $15-\mathrm{kV}$ acceleration voltage and 6-nA beam current. The Phi-Rho-Z procedure was used for matrix correction. Natural mineral standards were used for calibration: adular ( $\mathrm{Si}, \mathrm{K}$ and $\mathrm{Al}$, EDS) garnet ( $\mathrm{Mg}$ and $\mathrm{Fe} \mathrm{EDS}$ ), titanite ( $\mathrm{Ti}$ and $\mathrm{Ca}, \mathrm{EDS}$ ) on, $\mathrm{Mn}$ and $\mathrm{Cl}$ (EDS) on rhodonite and atacamite, respectively. $\mathrm{Na}$ and $\mathrm{F}$ were analysed by WDS using albite and synthetic F-phlogopite standards. Si, $\mathrm{Al}, \mathrm{Mg}$ and $\mathrm{Fe}$ were standardized on garnet in the case when garnet is analysed.

\section{Electron microprobe (EMP) monazite dating}

EMP dating was performed at Institute of Mineralogy, Technical University Freiberg, Germany and follows the procedure of Schulz (2017). EMP-Th-U-Pb dating is based on the observation that common $\mathrm{Pb}$ in monazite (LREE, Th) $\mathrm{PO}_{4}$ is negligible when compared to radiogenic $\mathrm{Pb}$ resulting from the decay of Th and U (Montel et al. 1996). Electron microprobe analysis of the bulk $\mathrm{Th}, \mathrm{U}$ and $\mathrm{Pb}$ concentrations 
in monazite, at a constant ${ }^{238} \mathrm{U} /{ }^{235} \mathrm{U}$ ratio, allows for the calculation of a chemical model age (CHIME) with a considerable error (Suzuki et al. 1994; Montel et al. 1996; Suzuki and Kato 2008; Spear et al. 2009). The M $\alpha 1$ lines of Th and Pb and the M $\beta 1$ lines for $U$ of a PET crystal were selected for monazite analysis. Analytical errors of $2 \sigma$ at $20 \mathrm{kV}$ acceleration voltage, $100 \mathrm{nA}$ beam current, $5 \mu \mathrm{m}$ beam diameter and counting times of $320 \mathrm{~s}(\mathrm{~Pb}), 80 \mathrm{~s}(\mathrm{U})$ and $40 \mathrm{~s}(\mathrm{Th})$ on peak have been considered for the calculation of ages. For $\mathrm{Pb}$, the error ranges typically from 0.016 to $0.024 \mathrm{wt} \%$ for the given dwell time, based on measurement on a reference monazite ("Madmon"; Schulz and Schüssler 2013). Detection limits $(1 \sigma)$ calculated from counting rates for elements with low concentrations in monazite are in element \%: Si 0.004; $\mathrm{Ca}$ 0.005; Y 0.020; Pb 0.006; U 0.016; Sm 0.060. Orthophosphates of the Smithsonian Institution were used as standards for REE analysis (Jarosewich and Boatner 1991). Calibration of $\mathrm{PbO}$ was carried out on a crocoite standard. The $\mathrm{U}$ was calibrated on a metal standard. The reference monazite labelled "Madmon" with special $\mathrm{ThO}_{2}{ }^{*}-\mathrm{PbO}$ characteristics (Schulz and Schüssler 2013) was used for calibration and offline re-calibration of $\mathrm{ThO}_{2}$ as well as for the control of data. Interference of YL $\gamma$ on the PbM $\alpha$ line was corrected by linear extrapolation as proposed by Montel et al. (1996). An interference of ThM $\gamma$ on UM $\beta$ was also corrected. The number of single analyses varies with the grain size of the monazites, e.g. $1-4$ analyses in grains of $<30 \mu \mathrm{m}$ in diameter. Monazite chemical ages were first calculated using the methods of Montel et al. (1996). Weighted average ages for monazite populations calculated using Isoplot 3.0 (Ludwig 2001) are interpreted as the time of closure for the Th-U-Pb system of monazite during growth or recrystallization in the course of metamorphism. Ages were further determined using the $\mathrm{ThO}_{2}{ }^{*}-\mathrm{PbO}$ isochron method (CHIME) of Suzuki et al. (1994) and Montel et al. (1996) where $\mathrm{ThO}_{2}{ }^{*}$ is the sum of the measured $\mathrm{ThO}_{2}$ plus $\mathrm{ThO}_{2}$ equivalent to the measured $\mathrm{UO}_{2}$. This is based on the slope of a regression line in $\mathrm{ThO}_{2}{ }^{*}$ vs. $\mathrm{PbO}$ coordinates forced through zero. In all analysed samples, the model ages obtained by the two different methods agree exceptionally well.

\section{${ }^{40} \mathrm{Ar} /{ }^{39} \mathrm{Ar}$ age-dating}

${ }^{40} \mathrm{Ar} /{ }^{39} \mathrm{Ar}$ analyses largely follow descriptions given in Rieser et al. (2006) and Cao et al. (2017). Preparation of the samples before and after irradiation, ${ }^{40} \mathrm{Ar} /{ }^{39} \mathrm{Ar}$ analyses, and age calculations were carried out at the ARGONAUT Laboratory of the Department of Geography and Geology at the University Salzburg. The samples were crushed carefully with a hammer. The $200-250 \mu \mathrm{m}$ white mica and amphibole fractions were hand-picked under the microscope. Mineral concentrates were packed in aluminium-foil and placed in quartz vials. For calculation of the $J$ values, flux-monitors were placed between each 4-5 unknown samples. The sealed quartz vials were irradiated in the Rez reactor (Prague, Czechia) for $16 \mathrm{~h}$. Correction factors for interfering isotopes were calculated from 45 analyses of two Ca-glass samples and 70 analyses of two pure K-glass samples and are as follows: ${ }^{36} \mathrm{Ar} /{ }^{37} \mathrm{Ar}(\mathrm{Ca})=0.000225,{ }^{39} \mathrm{Ar} /{ }^{37} \mathrm{Ar}$ $(\mathrm{Ca})=0.000614,{ }^{38} \mathrm{Ar} /{ }^{39} \mathrm{Ar}(\mathrm{Ca})=0.011700$ and ${ }^{40} \mathrm{Ar} /{ }^{39} \mathrm{Ar}$ $(\mathrm{K})=0.0266$. Variations in the neutron flux were monitored using the DRA1 sanidine standard for which a ${ }^{40} \mathrm{Ar} /{ }^{39} \mathrm{Ar}$ plateau age of $25.03 \pm 0.05 \mathrm{Ma}$ was originally reported (Wijbrans et al. 1995). Here we use the revised value of $25.26 \pm 0.05 \mathrm{Ma}$ (van Hinsbergen et al. 2008). ${ }^{40} \mathrm{Ar} /{ }^{39} \mathrm{Ar}$ analyses were carried out using a UHV Ar-extraction line equipped with a combined MERCHANTEK TM UV/IR laser system and a VG-ISOTECHTM NG3600 mass spectrometer. Stepwise heating analyses of samples were performed using a defocused ( $\sim 1.5 \mathrm{~mm}$ diameter $) 25 \mathrm{~W} \mathrm{CO}_{2}$-infrared laser operating in $\mathrm{Tem}_{00}$ mode at wavelengths between 10.57 and $10.63 \mu \mathrm{m}$. The NG3600 is an $18-\mathrm{cm}$ radius $60^{\circ}$ extended geometry instrument, equipped with a bright Nier-type source operated at $4.5 \mathrm{kV}$. Measurements were performed on an axial electron multiplier in static mode. Peak-jumping and stability of the magnet were controlled by a Hall-probe. For each increment the intensities of ${ }^{36} \mathrm{Ar}$, ${ }^{37} \mathrm{Ar},{ }^{38} \mathrm{Ar},{ }^{39} \mathrm{Ar}$ and ${ }^{40} \mathrm{Ar}$ were measured, the baseline readings on mass 34.5 were subtracted. Intensities of the peaks were back-extrapolated over 16 measured intensities to the time of gas admittance either by a straight line or a curved fit, depending on the intensity and type of the pattern of the evolving gas. Intensities were corrected for system blanks, background, post-irradiation decay of ${ }^{37} \mathrm{Ar}$ and interfering isotopes. Isotopic ratios, ages and errors for individual steps were calculated following suggestions by McDougall and Harrison (1999) and Scaillet (2000) using decay factors reported by Steiger and Jäger (1977). Definition and calculation of plateau ages were carried out using ISOPLOT/EX (Ludwig 2003).

\section{References}

Agard P, Omrani J, Jolivet L, Mouthereau F (2005) Convergence history across Zagros (Iran): constraints from collisional and earlier deformation. Int J Earth Sci (Geol Rundsch) 94:401-419

Agard P, Omrani J, Jolivet L, Whitchurch H, Vrielynck B, Spakman W, Monié P, Meyer B, Wortel R (2011) Zagros orogeny: a subduction-dominated process. Geol Mag 148:692-725

Baharifar AA (1997) New perspective on petrogenesis of the regional metamorphic rocks of Hamadan area. MSc thesis (in Persian), Tarbiat Moallem University of Tehran, Iran

Baharifar AA, Moinevaziri H, Bellon H, Piqué A (2004) The crystalline complexes of Hamadan (Sanandaj-Sirjan zone, western Iran): metasedimentary Mesozoic sequences affected by Late Cretaceous tectono-metamorphic and plutonic events. Comptes Rendus Geosci 336:1443-1452 
Berberian M, King GCP (1981) Towards a paleogeography and tectonic evolution of Iran. Can J Earth Sci 18:210-265

Cao S, Neubauer F, Bernroider M, Genser J, Liu J, Friedl G (2017) Low-grade retrogression of a high-temperature metamorphic core complex: Naxos, Cyclades, Greece. Geol Soc Am Bull 129:93117. https://doi.org/10.1130/B31502.1

Cherniak DJ, Watson EB, Grove M, Harrison TM (2004) Pb diffusion in monazite: a combined RBS/SIMS study. Geochim Cosmochim Acta 68:829-840

Chiu HY, Chung SL, Zarrinkoub MH, Mohammadi SS, Khatib MM, Iizuka Y (2013) Zircon U-Pb age constraints from Iran on the magmatic evolution related to Neotethyan subduction and Zagros orogeny. Lithos 162:70-87

Cohen KM, Finney SC, Gibbard PL, Fan JX (2013) The ICS international chronostratigraphic chart. Episodes 36:199-204

Connolly JAD, Cesare B (1993) C-O-H-S fluid compositions and oxygen fugacity in graphitic metapelites. J Metamorph Geol 11:379-388

Dachs E (1998) PET: petrological elementary tool for mathematica. Comput Geosci 24:219-235

Dachs E (2004) PET: petrological elementary tool for mathematica: an update. Comput Geosci 30:173-182

Davoudian AR, Genser J, Neubauer F, Shabanian N (2016) ${ }^{40} \mathrm{Ar} /{ }^{39} \mathrm{Ar}$ mineral ages of eclogites from North Shahrekord in the SanandajSirjan Zone, Iran: implications for the tectonic evolution of Zagros orogen. Gondwana Res 37:216-240

de Capitani C, Brown TH (1987) The computation of chemical equilibria in complex systems containing non-ideal solution. Geochim Cosmochim Acta 51:2639-2652

de Capitani C, Petrakakis K (2010) The computation of equilibrium assemblage diagrams with Theriak/Domino software. Am Mineral 95:1006-1016

Dehghan M (1947) Sur l'âge mésozoique de la zone de Hamadan (Iran septentrional). Comptes Rendus l'Acad Sci Paris 224:1516-1518

Eghlimi B (2000) Geological map of Hamadan, scale 1:100,000. Geological Survey of Iran, Tehran

Engi M, Lanari P, Kohn MJ (2017) Significant ages-an introduction to petrochronology. Rev Mineral Geochem 83:1-12

Fergusson CL, Nutman AP, Mohajjel M, Bennett VC (2016) The Sanandaj-Sirjan Zone in the Neo-Tethyan suture, western Iran: Zircon $\mathrm{U}-\mathrm{Pb}$ evidence of late palaeozoic rifting of northern Gondwana and mid-Jurassic orogenesis. Gondwana Res 40:43-57

François T, Agard P, Bernet M, Meyer B, Chung SL, Zarrinkoub MH, Burov E, Monié P (2014) Cenozoic exhumation of the internal Zagros: first constraints from low-temperature thermochronology and implications for the build-up of the Iranian plateau. Lithos 206:100-112

Harrison TM (1981) Diffusion of ${ }^{40} \mathrm{Ar}$ in hornblende. Contrib Mineral Petrol 78:324-331

Harrison TM, Celerier J, Aikman AB, Hermann J, Heizler M (2009) Diffusion of ${ }^{40} \mathrm{Ar}$ in muscovite. Geochim Cosmochim Acta 73:1039-1051

Hassanzadeh J, Wernicke BP (2016) The Neotethyan Sanandaj-Sirjan zone of Iran as an archetype for passive margin-arc transitions. Tectonics 35:586-621

Hoisch TD (1990) Empirical calibration of six geobarometers for the mineral assemblage quartz + muscovite + biotite + plagioclase + garnet. Contrib Mineral Petrol 104:225-234

Holdaway MJ (2000) Application of new experimental and garnet Margules data to the garnet-biotite geothermometer. Am Mineral $85: 881-892$

Holland TJB, Powell R (1998) An internally consistent thermodynamic data set for phases of petrological interest. J Metamorph Geol 16:309-344

Jamshidi Badr M, Masoudi F, Collins AS, Cox G (2010) Dating of Precambrian metasedimentry rocks and timing of their metamorphism in the Soursat metamorphic complex (NW Iran): using
LA-ICP-MS, U-Pb dating of zircon and monazite. J Sci Islam Repub Iran 21:311-319

Jarosewich E, Boatner LA (1991) Rare-earth element reference samples for electron microprobe analysis. Geostand Newslett 15:397-399

Koziol AM (1989) Recalibration of the garnet-plagioclase- $\mathrm{Al}_{2} \mathrm{SiO}_{5}-$ quartz (GASP) geobarometer and application to natural parageneses. EOS 70:493

Kretz R (1983) Symbols for rock-forming minerals. Am Mineral $68: 277-279$

Ludwig KR (2001) Users manual for isoplot/Ex rev. 2.49. A geochronological toolkit for Microsoft Excel, vol 1a. Berkeley Geochronology Center, Berkeley, pp 1-55

Ludwig KR (2003) Users manual for Isoplot/Ex version 3.0: a geochronological toolkit for Microsoft Excel, vol 4. Berkeley Geochronology Center Special Publication, Berkeley, p 70

Mahmoudi S, Corfu F, Masoudi F, Mehrabi B, Mohajjel M (2011) $\mathrm{U}-\mathrm{Pb}$ dating and emplacement history of granitoid plutons in the northern Sanandaj-Sirjan Zone. Iran J Asian Earth Sci 41:238-249

McDougall I, Harrison TM (1999) Geochronology and thermochronology by the ${ }^{40} \mathrm{Ar} /{ }^{39} \mathrm{Ar}$ method. Oxford University Press, New York, p 212

McFarlane CRM, Harrison TM (2006) Pb-diffusion in monazite: constraints from a high-T contact aureole setting. Earth Planet Sci Lett 250:376-384

Miri M, Sepahi AA, Aliani F, Maanijou M (2016) Chemical zoning of Ca-amphiboles in amphibolites, from the Hamedan area. West Iran Arab J Geosci 9:619. https://doi.org/10.1007/s1251 7-016-2652-y

Mohajjel M, Fergusson CL (2014) Jurassic to Cenozoic tectonics of the Zagros Orogen in northwestern Iran. Int Geol Rev 56(3):263-287

Mohajjel M, Fergusson CL, Sahandi MR (2003) Cretaceous-Tertiary convergence and continental collision, Sanandaj-Sirjan Zone, western Iran. J Asian Earth Sci 21:397-412

Mohajjel M, Baharifar AA, Moinevaziri H, Nozaem R (2006) Deformation history, micro-structure and $P-T-t$ path in ALS-bearing schists, southeast Hamadan, Sanandaj-Sirjan zone. Iran J Geol Soc Iran 1:11-19

Montel JM, Foret S, Veschambre M, Nicollet N, Provost A (1996) Electron microprobe dating of monazite. Chem Geol 131:37-53

Mottram CM, Warren CJ, Regis D, Roberts NMW, Harris NBW, Argles TW, Parrish RR (2014) Developing an inverted Barrovian sequence; insights from monazite petrochronology. Earth Planet Sci Lett 403:418-431

Pattison DRM (1992) Stability of andalusite and sillimanite and the $\mathrm{Al}_{2} \mathrm{SiO}_{5}$ triple point: constraints from the Ballachulish aureole. J Geol 100:423-446

Pattison DRM (2006) The fate of graphite in prograde metamorphism of pelites: an example from the Ballachulish aureole, Scotland. Lithos 88:85-99

Pattison DRM, Spear FS (2018) Kinetic control of staurolite- $\mathrm{Al}_{2} \mathrm{SiO}_{5}$ mineral assemblages: implications for Barrovian and Buchan metamorphism. J Metamorph Geol 36:667-690

Pattison DRM, Tracy RJ (1991) Phase equilibria and thermobarometry of metapelites. In: Kerrick DM (ed) Contact metamorphism, vol 26. Mineralogical Society of America, Chantilly, pp 105-206

Pattison DRM, Spear FS, de Buhr CL, Cheney JT, Guidotti CV (2002) Thermodynamic modelling of the reaction muscovite + cordierite $\rightarrow \mathrm{Al}_{2} \mathrm{SiO}_{5}+$ biotite + quartz $+\mathrm{H}_{2} \mathrm{O}$ : constraints from natural assemblages and implications for the metapelitic petrogenetic grid. J Metamorph Geol 20:99-118

Perchuk LL (1969) Garnet-clinopyroxene equilibrium as an indicator of temperature of deep-seated rocks. Isvestiya Acad Nauk USSR 6:144-169

Rieser AB, Liu YJ, Genser J, Neubauer F, Handler R, Friedl G, Ge $\mathrm{XH}(2006){ }^{40} \mathrm{Ar} /{ }^{39} \mathrm{Ar}$ ages of detrital white mica constrain the 
Cenozoic development of the intracontinental Qaidam Basin, China. Geol Soc Am Bull 118:1522-1534

Sabzehei M, Majidi B, Amidi M, Alavitehrani N, Ghorashi M (1977) Geological map of Iran, scale 1:250,000. Geological Survey of Iran, Tehran

Saki A, Moazzen M, Baharifar AA (2012) Migmatite microstructures and partial melting of Hamadan metapelitic rocks, Alvand contact aureole, western Iran. Int Geol Rev 54(11):1229-1240

Scaillet S (2000) Numerical error analysis in ${ }^{40} \mathrm{Ar} /{ }^{39} \mathrm{Ar}$ dating. Chem Geol 162:269-298

Schulz B (2017) Polymetamorphism in garnet micaschists of the Saualpe Eclogite Unit (Eastern Alps, Austria), resolved by automated SEM methods and EMP-Th-U-Pb monazite dating. J Metamorph Geol 35:141-163. https://doi.org/10.1111/jmg.12224

Schulz B, Schüssler U (2013) Electron-microprobe Th-U-Pb monazite dating in Early-Paleozoic high-grade gneisses as a completion of $\mathrm{U}-\mathrm{Pb}$ isotope ages (Wilson Terrane, Antarctica). Lithos 175-176:178-192

Sepahi AA, Whitney DL, Baharifar AA (2004) Petrogenesis of andalusite-kyanite-sillimanite veins and host rocks, Sanandaj-Sirjan metamorphic belt, Hamadan. Iran J Metamorph Geol 22:119-134

Sepahi AA, Jafari SR, Mani-Kashani S (2009) Low pressure migmatites from the Sanandaj-Sirjan Metamorphic Belt in the Hamedan region (Iran). Geol Carpath 60(2):107-119

Sepahi AA, Borzoe K, Salami S (2013) Mineral chemistry and thermobarometry of plutonic, metamorphic and anatectic rocks from the Tueyserkan area (Hamedan, Iran). Geol Q 57(3):515-526

Sepahi AA, Salami S, Lentz D, McFarlane C, Maanijou M (2018) Petrography, geochemistry, and U-Pb geochronology of pegmatites and aplites associated with the Alvand intrusive complex in the Hamedan region, Sanandaj-Sirjan zone, Zagros orogen (Iran). Int J Earth Sci (Geol Rundsch) 107:1059-1096

Sepahi AA, Jafari SR, Osanai Y, Shahbazi H, Moazzen M (2019) Age, petrologic significance and provenance analysis of the Hamedan low-pressure migmatites; Sanandaj-Sirjan Zone, west Iran. Int Geol Rev 61:1446-1461. https://doi.org/10.1080/00206 814.2018.1517392

Shahbazi H, Siebel W, Pourmoafee M, Ghorbani M, Sepahi AA, Shang CK, Vousoughi Abedini M (2010) Geochemistry and U-Pb zircon geochronology of the Alvand plutonic complex in Sanandaj-Sirjan Zone (Iran): new evidence for Jurassic magmatism. J Asian Earth Sci 39:668-683

Shakerardakani F, Neubauer F, Masoudi F, Mehrabi B, Liu X, Dong Y, Mohajjel M, Monfaredi B, Friedl G (2015) Panafrican basement and Mesozoic gabbro in the Zagros orogenic belt in the DorudAzna region (NW Iran): laser-ablation ICP-MS zircon ages and geochemistry. Tectonophysics 647-648:146-171

Spear FS, Pyle JM, Cherniak D (2009) Limitations of chemical dating of monazite. Chem Geol 266:227-239

Steiger RH, Jäger E (1977) Subcommission on geochronology: convention on the use of decay constants in geo- and cosmocchronology. Earth Planet Sci Lett 36:359-362

Stipp M, Stünitz H, Heilbronner R, Schmid SM (2002) The eastern Tonale fault zone: a 'natural laboratory' for crystal plastic deformation of quartz over a temperature range from 250 to $700{ }^{\circ} \mathrm{C}$. J Struct Geol 24:1861-1884

Stöcklin J (1968) Structural history and tectonics of Iran: a review. Am Assoc Pet Geol Bull 52:1229-1258

Suzuki K, Kato T (2008) CHIME dating of monazite, xenotime, zircon and polycrase: protocol, pitfalls and chemical criterion of possibly discordant age data. Gondwana Res 14:569-586

Suzuki K, Adachi M, Kajizuka I (1994) Electron-microprobe observations of $\mathrm{Pb}$ diffusion in metamorphosed detrital monazites. Earth Planet Sci Lett 128:391-405

Tinkham DK, Ghent ED (2005) Estimating $P-T$ conditions of garnet growth with isochemical phase diagram sections and the problem of effective bulk-composition. Can Mineral 43:35-50

Valizadeh MV, Cantagrel JM (1975) Premières données radiométriques ( $\mathrm{K}-\mathrm{Ar}$ et $\mathrm{Rb}-\mathrm{Sr}$ ) sur les micas du complexe magmatique dumont d'Alvand, près d'Hamadan (Iran occidental). Compte Rendue Acad Sci Paris Ser D 281:1083-1086

van Hinsbergen DJJ, Straathof GB, Kuiper KF, Cunningham WD, Wijbrans J (2008) No vertical axis rotations during Neogene transpressional orogeny in the NE Gobi Altai: coinciding Mongolian and Eurasian early Cretaceous apparent polar wander paths. J Geophys Res 173:105-126

Wijbrans JR, Pringle MS, Koppers AAP, Schveers R (1995) Argon geochronology of small samples using the Vulkaan argon laserprobe. Proc K Ned Akad Wet 98:185-218

Wu CM (2015) Revised empirical garnet-biotite-muscovite-plagioclase geobarometer in metapelites. J Metamorph Geol 33:167-176

Zhang ZY, Xiao WJ, Ji WQ, Majidifard MR, Rezaeian M, Talebian M, Xiang DF, Chen L, Wan B, Ao SJ, Esmaeili R (2018) Geochemistry, zircon $\mathrm{U}-\mathrm{Pb}$ and $\mathrm{Hf}$ isotope for granitoids, NW SanandajSirjan zone, Iran: implications for Mesozoic-Cenozoic episodic magmatism during Neo-Tethyan lithospheric subduction. Gondwana Res 62:227-245

\section{Affiliations}

\section{Behzad Monfaredi ${ }^{1}$ (1) $\cdot$ Christoph Hauzenberger ${ }^{1} \cdot$ Franz Neubauer $^{2} \cdot$ Bernhard Schulz $^{3} \cdot$ Johann Genser $^{2}$. Farzaneh Shakerardakani $^{4,5} \cdot$ Ralf Halama $^{6}$}

Behzad Monfaredi

monfaredi.b@hotmail.com

1 Department of Petrology and Geochemistry, NAWI Graz Geocenter, University of Graz, Universitätsplatz 2, $8010 \mathrm{Graz}$, Austria

2 Department of Geography and Geology, Paris-Lodron-University of Salzburg, Hellbrunner Str. 34, 5020 Salzburg, Austria

3 Institute of Mineralogy, Technical University Freiberg, Brennhausgasse 14, 09596 Freiberg, Sachsen, Germany
4 State Key Laboratory of Lithospheric Evolution, Institute of Geology and Geophysics, Chinese Academy of Sciences, Beijing 100029, China

5 Innovation Academy for Earth Science, Chinese Academy of Sciences, Beijing 100029, China

6 School of Geography, Geology and the Environment, Keele University, Keele, Staffordshire ST5 5BG, UK 